\title{
New Climatic Zones in Iran: A Comparative Study of Different Empirical Methods and Clustering Technique
}

\section{Faezeh Abbasi}

University of Tehran

Saeed Bazgeer ( $\sim$ sbazgeer@ut.ac.ir )

University of Tehran https://orcid.org/0000-0001-7044-0528

Parviz Rezazadeh Kalehbasti

I.R. of Iran Meteorological Organization (IRIMO)

\section{Ebrahim Asadi Oskoue}

Atmospheric Science and Meteorological Research Center

Masoud Haghighat

I.R. of Iran Meteorological Organization (IRIMO)

\section{Pouya Rezazadeh Kalebasti}

Stanford University,

\section{Research Article}

Keywords: Climatic classification, Climatic zones, Cluster analysis, Precipitation gradient, Thornthwaite and Mather method

Posted Date: June 2nd, 2021

DOl: https://doi.org/10.21203/rs.3.rs-570400/v1

License: (9) This work is licensed under a Creative Commons Attribution 4.0 International License. Read Full License

Version of Record: A version of this preprint was published at Theoretical and Applied Climatology on October 13th, 2021. See the published version at https://doi.org/10.1007/s00704-021-03785-9. 
Faezeh Abbasi ${ }^{1}$, Saeed Bazgeer ${ }^{2}$, Parviz Rezazadeh Kalehbasti ${ }^{3}$, Ebrahim Asadi Oskoue ${ }^{4}$, Masoud Haghighat ${ }^{5}$, Pouya Rezazadeh Kalebasti ${ }^{6}$

\section{New Climatic Zones in Iran: A Comparative Study of Different Empirical Methods and Clustering Technique}

${ }^{1}$ Faezeh Abbasi, Ph.D., Agricultural Climatology, Department of Physical Geography, Faculty of Geography, University of Tehran, Tehran, Iran

e-mail address: abbasi87@ut.ac.ir

2*Saeed Bazgeer, Corresponding author, Assistant Professor, Department of Physical Geography, Faculty of Geography, University of Tehran, Tehran, Iran e-mail address: sbazgeer@ut.ac.ir

Orcid Id: https://orcid.org/0000-0001-7044-0528

${ }^{3}$ Parviz Rezazadeh Kalehbasti, Synoptic Meteorologist, I.R. of Iran Meteorological Organization (IRIMO), Tehran, Iran e-mail address: rezazadeh.pr@gmail.com

${ }^{4}$ Ebrahim Asadi Oskoue, Assistant Professor, Department of Agricultural Meteorology, Atmospheric Science and Meteorological Research Center, Tehran, Iran e-mail address: e.asadi.o@gmail.com

${ }^{5}$ Masoud Haghighat, Agricultural Meteorologist, I.R. of Iran Meteorological Organization (IRIMO), Tehran, Iran

e-mail address: mhagigat@gmail.com

${ }^{6}$ Pouya Rezazadeh Kalebasti, Ph.D. student in civil and environmental engineering, Department of civil and environmental engineering, Stanford University, California, USA e-mail address: pouyar@stanford.edu

Acknowledgments The authors gratefully acknowledge the I.R. of Iran Meteorological Organization (IRIMO) for providing meteorological data from synoptic stations.

Funding information This research was supported by Iran National Science Foundation (INSF) by grant No. 2016/95838893.

Conflicts of interest The authors declare that there is no conflict of interest regarding the publication of this article.

Funding information This study was supported by the Iran National Science Foundation (INSF) , Grant No. 95838893. 


\begin{abstract}
It is a scientifically novel insight to classify the climate of a region using empirical methods together with clustering technique for practical usage in agricultural and industrial sectors. The main objective of this study is to compare the empirical approach to climate classification (Thornthwaite and Mather, De Martonne, the Extended De Martonne and the IRIMO (I.R. of Iran Meteorological Organization)) with clustering technique, Ward's hierarchical agglomerative method over Iran. The maximum and minimum temperatures and precipitation data of 356 weather stations are used from IRIMO databases. 35 synoptic weather stations are selected for detailed inspection based on appropriate geographical distribution and availability of a continuous 50-year data (1966-2015). Compared with the three empirical reference methods of climate classification, the Thornthwaite and Mather method clearly shows the role of water bodies and air masses for determining the climate type in different regions. This factor is identified as the main advantage of this method over the three others. This superiority is the most visible for the highlands/mountainous regions, in the vicinity of the Zagros Mountains, and in the western regions of Iran. As a case in point, while in the De Martonne and the Extended De Martonne methods, the Zagros storm cell is climatically classified similar to patchy areas in Caspian Sea coastal zone, this cell is correctly identified as a separate zone in the Thornthwaite and Mather method. The results revealed that the clusters obtained from Ward's algorithm are comparable to those of empirical climate classifications, particularly Thornthwaite and Mather method.
\end{abstract}

Keywords: Climatic classification, Climatic zones, Cluster analysis, Precipitation gradient, Thornthwaite and Mather method

\title{
1 Introduction
}

A comprehensive understanding of the climate characteristics in different regions is essential for environmental planning to achieve sustainable development. Climate classification is one reasonable way to achieve this purpose (Aparecido et al. 2016; Pieri et al. 2017). Climate classification is an attempt to identify and detect the climatic differences and similarities in various geographic regions and discover the relationships among different components of the climatic system. Studying the evolution of climate classification methods shows that recognizing climatic zones has been a concern for many scientists from the time of Ancient Greece (Feddema 2005), and it has led to developing various methods of climate classification. The oldest climate classification dates back to the ancient Greece periods (Feddema 2005) when Parmenides made the first global climatic classification according to the subtropical and polar circles in the $500 \mathrm{BC}$. Hipparchus also made another classification based on the solar inclination angle in the summer solstice. Later, Ptolemy classified the world into seven climates on the basis of latitudes. Development of different types of climate classifications continued with empirical relationships proposed by De Martonne (1941), Köppen (1900), Thornthwaite (1948) and Strahler (1978). Some of these methods, such as those of Thornthwaite and Mather (1955), Köppen-Geiger (1931), and Extended De Martonne (Khalili 1973), were modified by adding new climatic components. Thanks to recent developments in statistical methods, researchers have added new variables to identify the climates of the study areas with a higher accuracy. These researchers believe that empirical (traditional) methods cannot express the climatic facts of different geographic zones due to complexities of the climate system, since they cannot be classified by examining a limited number of climate variables. In addition, these types of classifications show little compatibility with the countries' biodiversity (Rahimi et al. 2013). However, comparing the climate zones of different regions using empirical methods is still the main concern of researchers studying climatic classification (Feddema 2005; Baltas 2007; Leech 2013; Papavasileiou and Mavrakis 2013; Aparecido et al. 2016; Piri, et al. 2017; Rubel et al. 2017; Vieira et al. 2017). Many meteorological studies in Iran have focused on climate classification. The first studies based on empirical methods carried out by Ganji (1954), Adl (1960), Javadi (1966) and Khalili (1973), used the Köppen method. Despite criticism about empirical methods, these methods have also been of interest to researchers in recent years. Scientists have recently adopted a new approach for studying climate zones of Iran using empirical methods. This approach mainly emphasizes the role of climate change in the margin shifts of climate zones (Poormohammadi and Malekinejad 2013; Rahimi et al. 2013; Siabi and Sanaenejad 2013; Zarei 2014; Bazrafshan Daryasari et al. 2015; Ghorbani et al. 2016; Mirmousavi and Kiani 2017; Raziei et al. 2017). As noted earlier, researchers in recent years have paid more attention to using quantitative methods, particularly Factor Analysis and clustering, to identify variables affecting the climate of the region under study (e.g. Heidari and Alijani 2000, Masoudian 2003). Modern statistical methods in climate classification have tried to overcome the shortcomings of traditional methods: studies on these methods show that climatic factors affecting empirical methods such as temperature and precipitation need to be addressed as effective factors in determining climate boundaries in a modern method (Golkar Hamzee Yazd et al. 
2016, Netzel and Stepinski 2016). Some studies have also emphasized on the effect of characteristics of the climatic variables, such as temperature or precipitation (Ghaffari 2003). Dinpajouh et al. (2003) also classified climate of Iran based on precipitation using multivariate methods. They selected 12 out of 57 climatic variables and divided the whole country into 6 homogeneous and one heterogeneous zone. Among the former accounts, the Köppen classification system is recognized as one of the most common classification methods. Later, the Thornthwaite and Mather classification (1955) presented an improved method in comparison with Köppen. In this method, in addition to temperature and precipitation, the evapotranspiration is considered as well. It is possible to identify the impact of moisture index on climate types in a region using Thornthwaite and Mather method. According to this fact, researchers believe this method is more suitable for agricultural planning than Köppen's method (Abounoori 2010; Muller et al. 2018; Umar et al. 2019). Feddema (2005) states that this classification method reveals properly the relationship between the climate variations and moisture index, temperature and dynamic characteristics of different regions. Despite its higher precision, computational complexities have made this method less popular than Köppen's method in the literature. However, Köppen uses mean monthly values and the most potent factor of precipitation can only be estimated and comparisons between localities cannot be made (Abounoori 2010). In addition, Köppen's scheme ignores other factors, such as cloudiness and wind. The climate zones in Iran are mostly identified using De Martonne and Köppen methods, and the Thornthwaite and Mather method (1955) [referred to as T\&M going forward] has not been used for this purpose to date. The present study adopts T\&M to classify Iran's climate using empirical methods augmented with T\&M (1955) while preserving homogeneous climatic classes for comparison with other climatic regions of the world. Further, De Martonne (1941), extended De Martonne (Khalili 1973) and IRIMO climate classification methods along with a hierarchical clustering technique, Ward's algorithm, are used to provide a frame of reference to assess the performance of T\&M and to determine which classification method is more aligned with the climate facts of Iran. Climatic zoning is further performed using geostatistical interpolation techniques considering the secondary variables, altitude and latitude, affecting temperature and precipitation.

\section{Data and methodology}

\subsection{Climatic features of Iran}

Iran is located in the Middle East, a recognized geographical region of southwest Asia. Iran situated between latitudes $25^{\circ} 03^{\prime}-39^{\circ} 47^{\prime} \mathrm{N}$ and longitudes $44^{\circ} 05^{\prime}-63^{\circ} 18^{\prime} \mathrm{E}$ and covers an area of about 1.65 million $\mathrm{km}^{2}$ (Ghaemi et al. 2012). The country bordered by the Caspian Sea, Persian Gulf and Oman Sea, and by the countries of Iraq, Turkey, Azerbaijan, Turkmenistan, Afghanistan and Pakistan (Fig. 1). Iran is a rugged country of plateaus and mountains dominated by the Alborz Mountains in the north and the Zagros Mountains along its western border (Zarei et al. 2013).

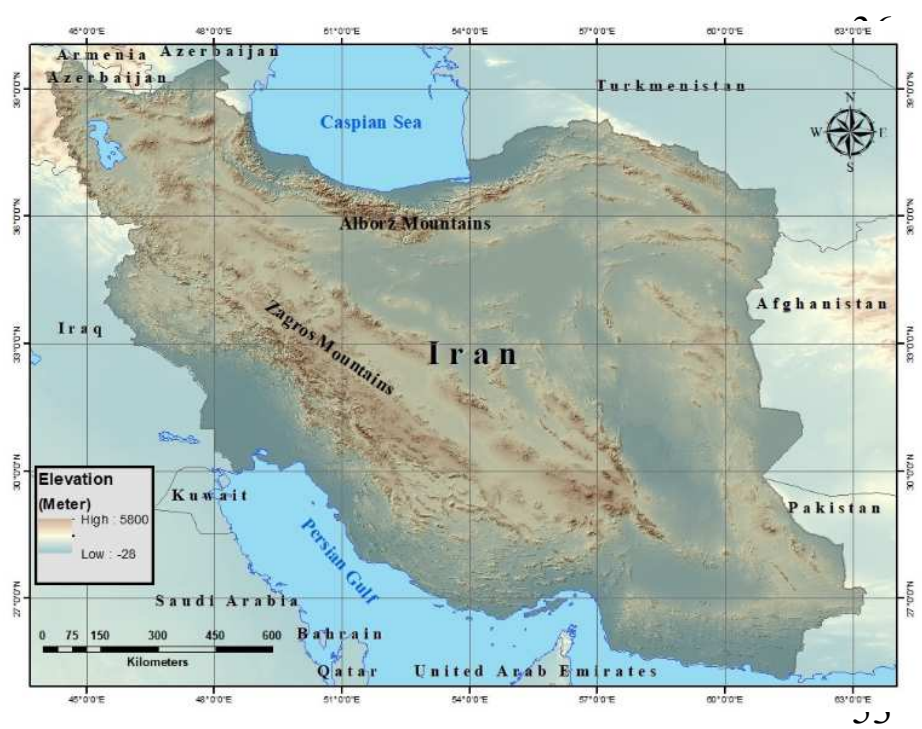

Fig. 1 The study area

55 Iran's climate is mostly arid and semi-arid (Alavipanah et al. 2007) and is controlled by various factors. The 56 relatively consistent characteristics that exit, the different climates of Iran are mainly due to latitude, topography and 
proximity to large water bodies, and also different impacts of the atmospheric systems on the country due to their frequency and intensity. The effect of topography on the arrangement of different climatic regions of Iran is very important, especially the Zagros and Alborz Mountains which determine the spatial variations of temperature and precipitation. Regarding these fact, climatic borders of Iran largely follow the topographies. The external factors affecting the climate of the country are mainly the components of the general circulation of the atmosphere, including the subtropical high (STH), the upper westerly winds, the Mediterranean Sea and trough, the polar front jet, the Sudan low pressure and the Red sea inverted trough, the Arabian Sea and Indian ocean. The Rossby Waves passing north of Caspian Sea have the major role on precipitation in South Caspian Sea coastal area, especially in provinces located in its southwestern part. The role of humidity flux from Caspian Sea on heavy rainfall in its coastal provinces is very prominent. The humidity flux from Arabian Sea, the northern region of the Indian Ocean and the Red Sea contribute very much in feeding the precipitate system of the Rossby Waves passing over the Mediterranean. In addition to strengthening the Mediterranean cyclones when they are moving towards Iran, the low level stationary anticyclone on the Arabian Peninsula intensifies the feeding of warm and humid air into the warm sector of precipitating systems. Actually the heavy and widespread precipitations are usually formed in Iran under this mechanism. The origin of the Mediterranean cyclones is either itself or the low-pressures along with the Roseby waves comming from Western Europe and intensify over center or eastern part of this water body. The windward side of Zagros Mountains in west of Iran are affected by the Mediterranean frontal systems intensified by orographic forcing. In warm season; the areas in the north of Persian Gulf and north of the Oman Sea are affected by monsoon south easterly winds passing over Oman Sea and Persian Gulf. Overall, Iran with a broad geographic location has always been under the influence of various atmospheric systems due to the general circulation of the atmosphere (Moradian 2016). The average annual precipitation in Iran is $245 \mathrm{~mm}$. The rainfall in the desert areas is less than 50 mm (I.R. of Iran Meteorological Organization, IRIMO 2016) and over 800mm in the south of Caspian Sea (North of Iran). Precipitation in 61 percent of the country is less than $250 \mathrm{~mm}$, and only 4 percent in the country has precipitation more than $800 \mathrm{~mm}$. Despite the proximity to the water resources of the Persian Gulf and the Oman Sea; The southern coasts of the country have little rainfall due to other required mechanism such as polar front jet stream, cloud and precipitation formation (Masoudian 2011). Air temperature in Iran is highly dependent on altitude, latitude, and atmospheric moisture. The effect of altitude on the air temperature is more considerable than the latitude. The average annual temperature is 18 degree centigrades and decreases from east to west and south to north. The effect of latitude on the temperature difference in regions is more than that of longitude. The spatial gradient of temperature rises 2.6 and 7.8 degree Celsius for every $10000 \mathrm{~km}$ from west to east and north to south of the country, respectively. The increase in temperature from west to east is due to the concentration of the massive mountains in the west and from north to south due to approaching to equator and the increasing of the solar radiation angle. Climate of Iran is divided in to 6 temperature regions, including cold, semi-cold, moderate, semi-warm, warm and very warm with an average temperature of $11,13.5,16.1,19.5,23.7$ and 26 degree Celsius, respectively (Masoudian 2011).

\subsection{Data}

Meteorological data, including maximum and minimum temperatures and precipitation of 356 weather stations are from I.R. of Iran Meteorological Organization. Based on optimal spatial distribution of the weather station networks and availability of a continuous 50-year data set for each station (1966-2015); 35 synoptic weather stations were selected (Fig. 2 and Table 1). 


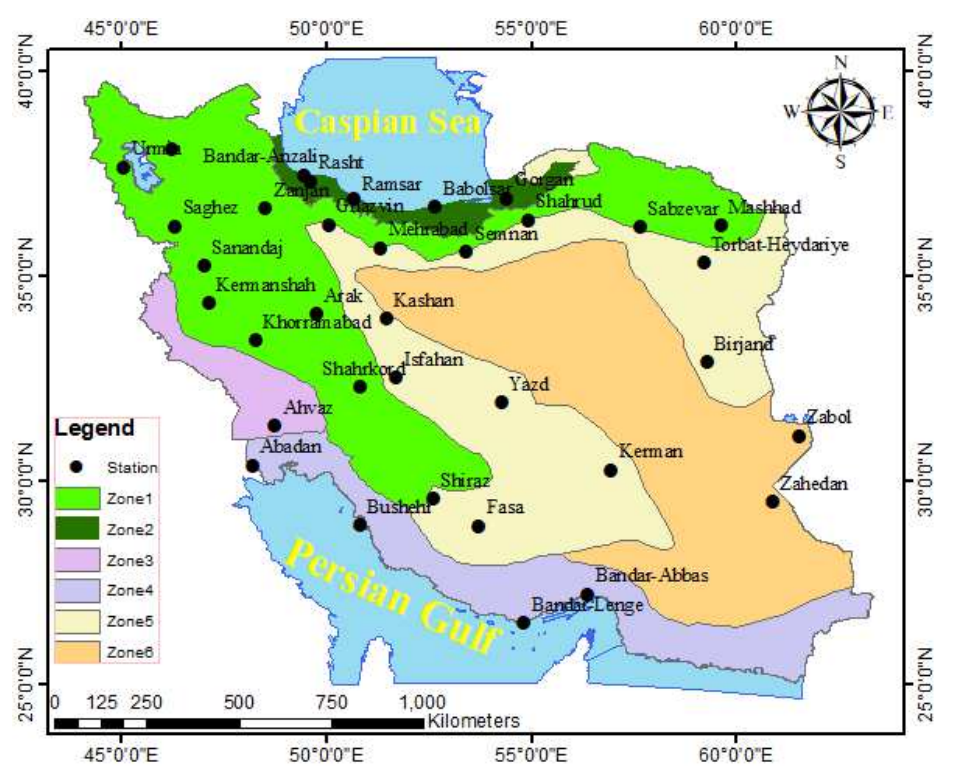

Fig. 2 Different climatic zones in Iran along with location of weather stations (IRIMO, 2016) Zone 1: Cold to very cold with moderate rainfall; Zone 2: Temperate with lots of rainfall; Zone 3: Slightly Warm with moderate rainfall; Zone 4: Very warm with low rainfall; Zone 5: Hot with low rainfall; Zone 6: Very hot with very low rainfall

The missed values were filled by average daily data for each station. For example, if the station's minimum temperature value was missing for a day, the long-term average (50-year period) of the same day for the station is used to fill the missing data. Data retrieval was done based on the report of the World Meteorological Organization (Aguilar et al. 2003) according that the data gaps should be less than 10 percent. Among the 35 stations, only missing data (11.1\%) of minimum temperature in Bandar Anzali station (north of Iran, Fig. 2) exceeded the permissible limit for data gaps. The percentage of data gaps in maximum and minimum temperatures and precipitation were mostly within the range of $0-1$ percent (Table 2) for the remaining stations.

Table 1 Weather stations metadata with percentage of missing values of minimum $\left(\mathrm{T}_{\min }\right)$ and maximum ( $\left.\mathrm{T}_{\max }\right)$ temperatures and precipitation $(\mathrm{P})$ data (1966-2015)

\begin{tabular}{|c|c|c|c|c|c|c|c|}
\hline \multirow[t]{2}{*}{$\mathrm{S} / \mathrm{N}$} & \multirow[t]{2}{*}{ Weather stations } & \multirow{2}{*}{$\begin{array}{l}\text { Latitude } \\
\text { (degree) }\end{array}$} & \multirow{2}{*}{$\begin{array}{c}\text { Longitude } \\
\text { (degree) }\end{array}$} & \multirow{2}{*}{$\begin{array}{c}\text { Elevation } \\
\text { (m) }\end{array}$} & \multicolumn{3}{|c|}{ Missing Values (\%) } \\
\hline & & & & & $\mathrm{T}_{\min }$ & $\mathrm{T}_{\max }$ & $\mathrm{P}$ \\
\hline 1 & Abadan & 30.30 & 48.20 & 6.60 & 7.64 & 5.25 & 0.33 \\
\hline 2 & Ahvaz & 31.30 & 48.70 & 22.5 & 0.29 & 0.30 & 0.22 \\
\hline 3 & Arak & 34.07 & 49.70 & 1702.80 & 2.39 & 0.09 & 0.04 \\
\hline 4 & Babolsar & 36.69 & 52.64 & -21.00 & 0.01 & 0.06 & 0.00 \\
\hline 5 & Bandar-e-Abbas & 27.20 & 56.30 & 9.80 & 5.81 & 1.11 & 0.03 \\
\hline 6 & Bandar-e-Anzali & 37.40 & 49.40 & -23.60 & 11.10 & 5.44 & 0.10 \\
\hline 7 & Bandare-e-lengeh & 25.52 & 54.82 & 22.7 & 1.80 & 3.03 & 0.08 \\
\hline 8 & Birjand & 32.80 & 59.20 & 1491.00 & 0.09 & 3.36 & 3.20 \\
\hline 9 & Bushehr & 28.90 & 50.80 & 8.40 & 0.26 & 0.46 & 2.92 \\
\hline 10 & Fasa & 28.80 & 53.70 & 1268.00 & 2.06 & 2.70 & 0.03 \\
\hline 11 & Gorghan & 36.90 & 54.40 & 7.00 & 3.28 & 2.96 & 0.02 \\
\hline 12 & Isfahan & 32.50 & 51.70 & 1550.40 & 0.19 & 0.15 & 0.09 \\
\hline
\end{tabular}




\begin{tabular}{|l|c|c|c|c|c|c|c|}
\hline 13 & Kashan & 33.96 & 51.48 & 955.00 & 6.50 & 1.69 & 0.14 \\
\hline 14 & Kerman & 32.20 & 56.90 & 1754.00 & 0.06 & 0.07 & 0.09 \\
\hline 15 & Kermanshah & 34.30 & 47.10 & 1318.50 & 0.31 & 0.27 & 0.12 \\
\hline 16 & Khoramabad & 33.40 & 48.20 & 1147.80 & 0.15 & 0.12 & 0.00 \\
\hline 17 & Mashhad & 36.20 & 59.60 & 999.20 & 4.26 & 5.04 & 0.04 \\
\hline 18 & Mehrabad & 35.60 & 51.30 & 1191.00 & 0.07 & 0.09 & 0.00 \\
\hline 19 & Qazvin & 35.26 & 50.06 & 1279.10 & 5.73 & 1.94 & 0.04 \\
\hline 20 & Ramsar & 36.90 & 50.68 & -20.00 & 7.10 & 4.64 & 0.14 \\
\hline 21 & Rasht & 37.30 & 49.60 & -8.60 & 6.88 & 4.42 & 0.17 \\
\hline 22 & Sabzevar & 36.20 & 57.64 & 962.00 & 5.81 & 2.65 & 0.01 \\
\hline 23 & Sanandaj & 35.20 & 47.01 & 1373.40 & 4.31 & 0.62 & 0.00 \\
\hline 24 & Saqez & 36.22 & 46.31 & 1522.80 & 7.71 & 3.64 & 0.47 \\
\hline 25 & Semnan & 35.58 & 53.42 & 1127.00 & 2.69 & 2.40 & 0.16 \\
\hline 26 & Shahre Kord & 32.20 & 50.80 & 2048.90 & 0.04 & 0.05 & 0.04 \\
\hline 27 & Shahrud & 36.38 & 54.92 & 1325.20 & 0.13 & 0.13 & 0.09 \\
\hline 28 & Shiraz & 29.56 & 52.60 & 1488.00 & 4.17 & 2.73 & 0.12 \\
\hline 29 & Tabriz & 38.10 & 46.20 & 1361.00 & 6.39 & 4.14 & 0.02 \\
\hline 30 & Torbatheydarieh & 35.30 & 59.20 & 1451.00 & 0.34 & 0.36 & 0.13 \\
\hline 31 & Urmia & 37.60 & 45.05 & 1328.00 & 1.95 & 0.81 & 0.03 \\
\hline 32 & Yazd & 31.90 & 54.20 & 1230.20 & 2.25 & 0.14 & 0.03 \\
\hline 33 & Zabol & 31.08 & 61.50 & 489.20 & 0.32 & 1.32 & 0.24 \\
\hline 34 & Zahedan & 29.40 & 60.9 & 1370.00 & 0.08 & 0.15 & 0.00 \\
\hline 35 & Zanjan & 36.60 & 48.50 & 1659.40 & 0.13 & 0.09 & 0.14 \\
\hline
\end{tabular}

1

Table 2 The percentage of missing values of minimum $\left(\mathrm{T}_{\min }\right)$ \& maximum $\left(\mathrm{T}_{\max }.\right)$ temperatures and precipitation $(\mathrm{P})$ data (1966-2015)

\begin{tabular}{cccc}
\hline Classes $(\%)$ & $\mathrm{T}_{\min }\left({ }^{\circ} \mathrm{C}\right)$ & $\mathrm{T}_{\max }\left({ }^{\circ} \mathrm{C}\right)$ & $\mathrm{P}(\mathrm{mm})$ \\
\hline $0-1$ & 42.8 & 48.5 & 94.2 \\
$1-2$ & 5.8 & 11.5 & 0 \\
$2-3$ & 11.5 & 14.5 & 2.9 \\
$3-4$ & 2.8 & 8.5 & 2.9 \\
$4-5$ & 8.5 & 8.5 & 0.0 \\
$>5$ & 28.6 & 8.5 & 0.0 \\
\hline
\end{tabular}

4 5 6 7 8

\subsection{Data homogeneity test}

For environmental studies, the quality and validity of the data should be taken into account. This issue is one of the most important requirements for statistical analysis in atmospheric sciences, hydrology and other related fields. The homogeneity tests applied to temperature and precipitation data were Pettit homogeneity, Pettit 1979; standard normal homogeneity test (SNHT), Alexanderson and Moberg (1997); cumulative deviations, Buishand (1982) and likelihood ratio test, Worsley (1979). Data homogeneity tests carried out under different types of null hypothesis (Table 3). For Pettit and standard normal tests, if the p-value was higher than Alpha $(\alpha=0.05$, Alpha is the probability of type I error), the null hypothesis was accepted and hence data are homogeneous. For two other tests including cumulative deviations and likelihood ratio, the null hypothesis was true if "Q" and "W" were less than critical values(1.36 and 3.16), respectively (Table 3 ).

Table 3 Characteristics of homogeneity tests used in the study* 


\begin{tabular}{cccc}
\hline Test & Type & Null Hypothesis & Author \\
\hline Standard Normal Homogeneity & Parametric & $\mathrm{H}_{0}: \alpha<0.05$ & $\begin{array}{c}\text { Alexanderson \& Moberg } \\
\text { Test }\end{array}$ \\
Pettit & Non-parametric & $\mathrm{H}_{0}: \alpha<0.05$ & (1997) \\
Buishand & Parametric & $\mathrm{H}_{0}: \mathrm{Q} \leq 1.36$ & Buishand (1982) \\
Worsley & Parametric & $\mathrm{H}_{0}: \mathrm{W} \leq 3.16$ & Worsley (1979) \\
\hline * "Q" and "W" are critical values for cumulative deviations and likelihood ratio tests, respectively.
\end{tabular}

\subsection{Mapping Climate Data}

For climatic zoning, it is necessary to interpolate climatic data recorded at the station scale. The performance evaluation of inverse distance weighting (IDW) and Kriging methods was carried out using RMSE (Root Mean Square Error) for temperature, precipitation and evapotranspiration data interpolation. Cross-validation was used to evaluate the accuracy of interpolation methods. On the basis of observed and estimated values, the RMSE was calculated for each method (equation 1):

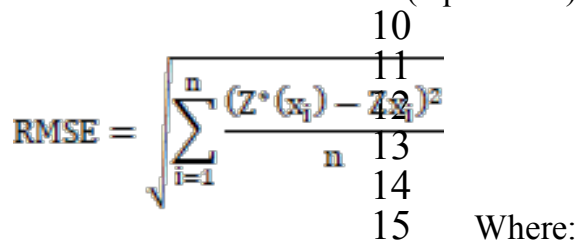

$16 \mathrm{n}$ is the number of data,

$17 \quad \mathrm{z}^{*}\left(\mathrm{x}_{\mathrm{i}}\right)$ is the estimated value at the point $\mathrm{x}$, and

$18 \mathrm{z}(\mathrm{xi})$ is the observed value.

19

\subsection{Climate Classification Methods}

DeMarton (De Martonne, 1941), Extended De Martonne (Khalili 1973) and T\&M (1955) methods are used for climate classification.

\subsubsection{De Martonne method}

The calculation of aridity index of De Martonne (1941) was based on the annual average temperature and precipitation (1966-2015), (equation 2). Table 4 shows the climate classes of De Martonne method.

$$
A_{I}=\frac{P}{T+10}
$$

Where:

$\mathrm{A}_{\mathrm{I}}$ is the De Martonne aridity index, $P$ the annual average precipitation $(\mathrm{mm})$, and $\mathrm{T}$ is the annual average temperature $\left({ }^{\circ} \mathrm{C}\right)$.

Table 4 Climatic Types and class intervals (De Martonne 1941)

\begin{tabular}{cccccccc}
\hline Class Intervals & 0 to 10 & 10 to 20 & 20 to 24 & 24 to 28 & 28 to 35 & 35 to 55 & 55 and above \\
\hline Climate Types & Dry & Semi-dry & Mediterranean & Semi-Humid & Humid & $\begin{array}{c}\text { Very Humid } \\
\text { (Type A) }\end{array}$ & $\begin{array}{c}\text { Very Humid } \\
\text { (Type B) }\end{array}$ \\
Symbol & $\mathrm{A}_{1}$ & $\mathrm{~A}_{2}$ & $\mathrm{~A}_{3}$ & $\mathrm{~A}_{4}$ & $\mathrm{~A}_{5}$ & $\mathrm{~A}_{6}$ & $\mathrm{~A}_{7}$ \\
\hline
\end{tabular}

\subsubsection{Extended De Martonne method}

Khalili (1973) attempted to represent more characteristics of Iran's climate by inserting some changes in classification of De Martonne (1941), with respect to comparative values on a global scale. This method was 
climate classification divides each climate class into four temperature subgroups. Table 5 shows the temperature subclasses corresponding to " $\mathrm{m}$ ".

Table 5 Temperature

\begin{tabular}{ccccc}
\hline Class Interval $\left({ }^{\circ} \mathrm{C}\right)$ & 5 and above & 5 to 0 & 0 to -7 & -7 and below \\
\hline Temperature Types & Warm & Moderate & Cold & Hyper-Cold \\
Symbol & $\mathrm{m}_{1}$ & $\mathrm{~m}_{2}$ & $\mathrm{~m}_{3}$ & $\mathrm{~m}_{4}$ \\
\hline
\end{tabular}

\subsubsection{Thornthwaite and Mather method}

The Thornthwaite (1948) method is one of the best for estimating the moisture balance (Feddema 2005). Thornthwaite emphasized the humidity and potential evapotranspiration (PE) in each region for climate condition classification. The procedure of calculating PE is based on the following equations:

$\mathrm{PE}=16\left(\frac{10 \mathrm{~T}}{\mathrm{I}}\right)^{\mathrm{n}}$

14 Where:

$15 \mathrm{~T}$ is the monthly mean air temperature $\left({ }^{\circ} \mathrm{C}\right)$, and

$16 \quad \mathrm{I}$ is the annual thermal index.

$\alpha$ is a constant coefficient expressed by the following relationships:

$$
\begin{aligned}
& \alpha=675 \times 10^{-9} \times \mathrm{I}^{3}-771 \times 10^{-7} \times \mathrm{I}^{2}+1792 \times 10^{-5} \times \mathrm{I}+49239 \times 10^{-5} \\
& 20 \\
& I=\sum_{n=1}^{21} i_{n}
\end{aligned}
$$

$\mathrm{i}=\left(\frac{\mathrm{I}}{5}\right)^{1.514}$

Where:

$\mathrm{i}$ is the monthly thermal index.

According to the actual day length (h) and the number of days per month $(\mathrm{N})$, the equation 3 was modified as (equation 7):

$\mathrm{PE}=\mathrm{PE}\left(\frac{\mathrm{N} \times \mathrm{h}}{360}\right)$

It should be noted that according to findings from previous study (Nouri Mohammadi et al. 2009), the calculated potential evapotranspiration was underestimated by Thornthwaite method (Thornthwaite 1948) for different regions of Iran. Therefore, optimum regional coefficient was used to increase the accuracy of the calculated PE by Thornthwaite method for different regions of the country. The coefficient ranged from 0.31 to 1.43 so that it was low in the summer months as compared to the winter months (Nouri Mohammadi et al. 2009). T\&M (1955) modified the 1948 Thornthwaite method and proposed the following equations to calculate the soil moisture changes and hence classifying the climate conditions of the regions (Equation 8).

$I_{m}=\left(\frac{W S-W D}{P E}\right) \times 100$

Soil moisture deficit (WD) is the difference between PE and AE, while surplus (WS) is calculated from equation 9 and 10 . 
Where:

$\mathrm{I}_{\mathrm{m}}$ is the thermal index,

$P$ is precipitation $(\mathrm{mm})$, and

$\mathrm{AE}$ is the actual evapotranspiration (mm). Table 6 shows the climate types for T\&M method.

Table 6 Climate types and class intervals for T\&M method (T\&M 1955)

\begin{tabular}{ccc}
\hline Climate Type & Class Interval & Symbol \\
\hline Arid & -60 to -40 & $\mathrm{E}$ \\
Semi-Arid & -40 to -20 & $\mathrm{D}$ \\
Dry Sub-Humid & -20 to 0 & $\mathrm{C} 1$ \\
Moist Sub-Humid & 0 to 20 & $\mathrm{C}_{2}$ \\
Humid & 20 to 40 & $\mathrm{~B}_{1}$ \\
Humid & 40 to 60 & $\mathrm{~B}_{2}$ \\
Humid & 60 to 80 & $\mathrm{~B}_{3}$ \\
Humid & 80 to 100 & $\mathrm{~B}_{4}$ \\
Very Humid & 100 and above & $\mathrm{A}$ \\
\hline
\end{tabular}

\subsubsection{IRIMO Method}

The IRIMO climate classification method (IRIMO 2016), is an accepted and reliable method which is elaborated for sustainable development purposes in Iran. It is based on monthly average minimum and maximum temperature and precipitation data. In addition, the altitude is considered as an effective variable on climate characteristics in IRIMO method. In IRIMO method, 6 climate regions were defined including, cold to very cold with moderate rainfall, temperate with lots of rainfall, slightly warm with moderate rainfall, very warm with low rainfall, hot with low rainfall, very hot with very low rainfall (Figure 2).

\subsection{Clustering}

Cluster analysis is a form of data reduction method and it is a technique that dividing the whole objects into classes that are homogeneous within themselves but heterogeneous between each other (Jain et al 1999; Norusis, 2010). In order to compare empirical climate classification methods with clustering techniques, a hierarchical clustering (Ward's method) was used. The squared Euclidean distance was employed for the distance measure and z-scores used for standardization of the data with different scales (Kent et al., 2014). The clustering of 35 weather stations was performed according to the seven criteria, including latitude, longitude, elevation, minimum and maximum temperatures, precipitation and evapotranspiration. Therefore, each cluster will correspond to a climatic group.

\section{Results}

\subsection{Trends of changes in minimum and maximum temperatures and precipitation}

Homogeneity tests were applied to minimum and maximum temperature and precipitation datasets. After four homogeneity tests, data were classified into acceptable, doubtful and suspect categories (Wijngaard et al. 2003). The results are presented in Table 7.

Table 7 Number of weather stations in different homogeneity classes*

\begin{tabular}{cccc}
\hline Classes & $\mathrm{T}_{\min }$ & $\mathrm{T}_{\max }$ & $\mathrm{P}$ \\
\hline Useful & 3 & 4 & 28 \\
Doubtful & 0 & 0 & 1 \\
Suspect & 32 & 31 & 6
\end{tabular}

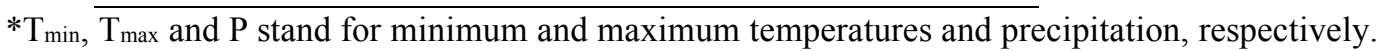


The spatial distribution of changes for the average minimum temperature trend in climatic classes of the country ranged from -2.8 to $+2.8^{\circ} \mathrm{C}$ (Figure 3). The highest changes along with significant upward trend are observed in northeast of Iran.

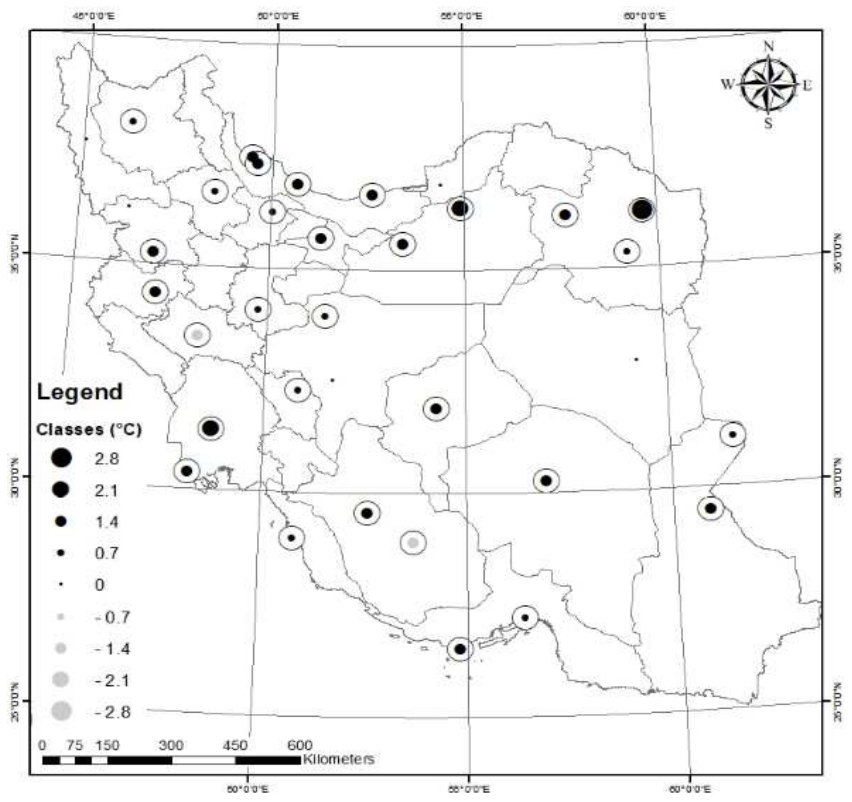

Fig. 3 Geographical distribution of trend in average minimum temperature changes $\left({ }^{\circ} \mathrm{C}\right)$ in weather stations (19662015); White circles indicate the significant trends $(\mathrm{p}<0.05)$

Figure 4 shows the spatial change distribution of the average maximum temperature trend. There are significant changes in most parts of the country, especially in the northern half of Iran. The highest and lowest trend were observed in Kermanshah and Babolsar with +1.8 and +0.8 changes, respectively (Fig. 4). Overall range of maximum temperature variations is generally lower than the minimum temperature.

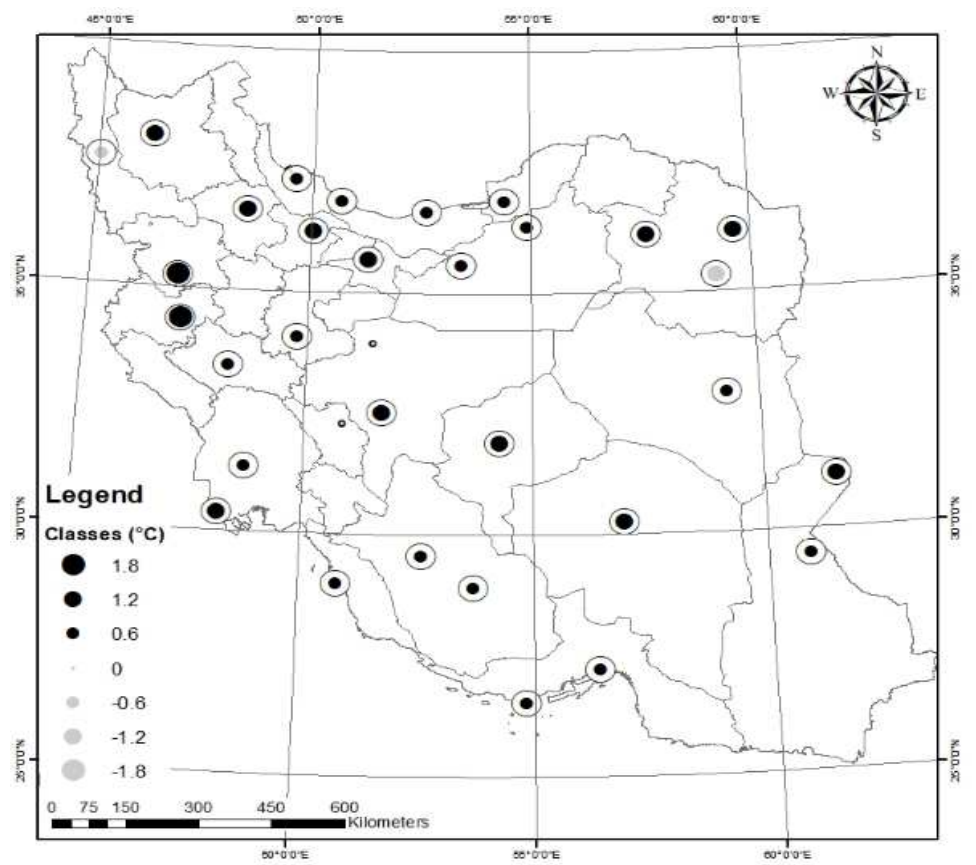

Fig. 4 Geographical distrıbution of average maxımum temperature ( c) trend in weather stations (1966-2015); White circles indicate a significant trend $(\mathrm{p}<0.05)$ 
Homogeneity tests applied to 35 weather stations revealed that precipitation data were homogeneous for 27 stations and heterogeneity was observed in 9 stations (Tabriz, Sanandaj, Saghez, Kermanshah, Gorgan, Kashan, Birjand, Kerman and Zabol). The highest and lowest average precipitation variations trend (1966-2015) was observed in Sanandaj and Kashan with a significant trend of $-156 \mathrm{~mm}$ and $+20.5 \mathrm{~mm}$, respectively (Fig. 5).

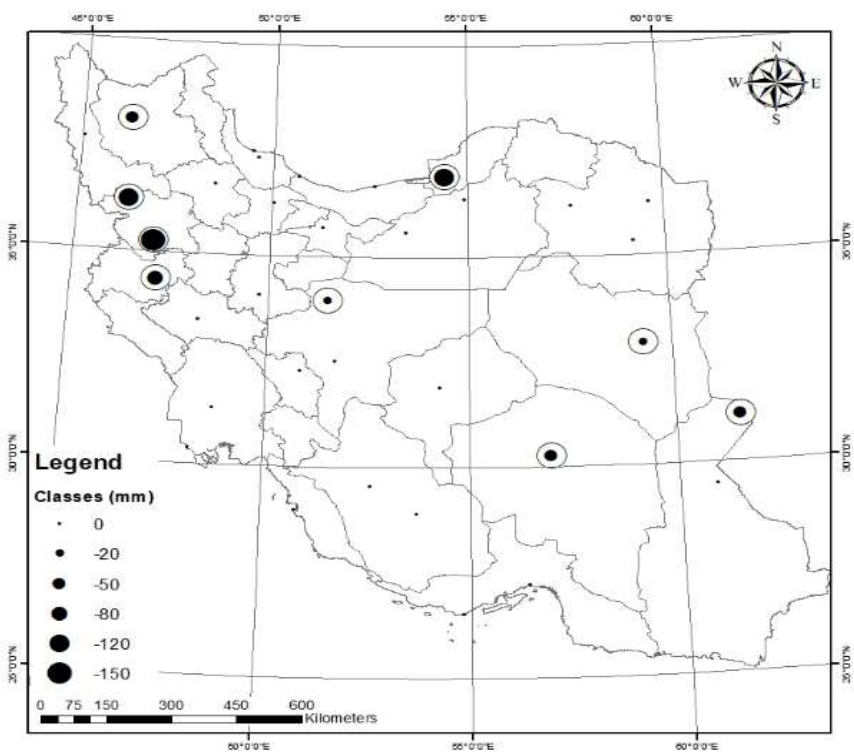

Fig. 5 Geographical distribution of the trend of average precipitation (mm) in weather stations (1966-2015); White circles indicated a significant trend $(\mathrm{p}<0.05)$

\subsection{Climate Classification}

Mapping the required essential variables is the first step toward the climate classification for each method. Therefore, the maps of the average temperature and precipitation for DeMarton method (De Martonne 1941), average monthly temperature in the coldest month of the year for extended DeMarton method (Khalili 1973), and potential evapotranspiration for T\&M method (T\&M 1955) were prepared.

\subsubsection{Statistical regression models}

In order to prepare the isoline maps for temperature, precipitation and evapotranspiration, we first developed the relationship between temperature, precipitation and evapotranspiration as dependent variables and altitude, longitude and latitude for independent variables. Table 8 shows the statistical models for average and minimum temperatures using multiple linear regressions for the country.

Table 8 Regression models for interpolation of average and minimum temperatures data used for the whole country

\begin{tabular}{cccccc}
$\begin{array}{l}\text { Response } \\
\text { Variables }\end{array}$ & Constant value with regression coefficients & Sig. (P-Value) & $\mathrm{R}$ & $\mathrm{R}^{2}$ & $\mathrm{SEOE}\left({ }^{\circ} \mathrm{C}\right)$ \\
$\mathrm{T}_{\text {avg. }}$ & 49.70-0.84 Lat. +0.023 Long.-0.005h & 0.000 & $0.937^{* *}$ & 0.878 & 1.8 \\
$\mathrm{~T}_{\text {min. }}$ & 30.60-0.813 Lat. +0.24 Long.-0.004h & 0.000 & $0.766^{* *}$ & 0.587 & 3.5 \\
\hline
\end{tabular}

$\mathrm{T}_{\text {avg: }}$ Average Temperature; $\mathrm{T}_{\min }$ : Minimum Temperatures; Lat.: Latitude; Long.: Longitude; h: Height; R: Multiple Correlation Coefficient; $\mathrm{R}^{2}$ : Coefficient of Determination; SEOE: Standard Error of Estimate; *Significant at 5 percent level $(\mathrm{P}<0.05) ; * *$ Significant at 1 percent level $(\mathrm{P}<0.01)$; ns: non-significant

Since the gradient of precipitation and potential evapotranspiration were not the same in different geographic regions of the country (Ghorbani and Aghashariatmadari 2014), therefore the statistical equations were derived separately for each climatic zone (Tables 9 and 10). In addition, no significant correlations were found in climate zones of 6 and 4 for precipitation and potential evapotranspiration, respectively, hence neither for zone 6 nor zone 4 equation was derived (Tables 9 and 10). 
Table 9 Regression models for interpolation of precipitation data used for different climatic zones

\begin{tabular}{|c|c|c|c|c|c|}
\hline Zones & $\begin{array}{c}\text { Constant value with regression } \\
\text { coefficients }\end{array}$ & Sig. (P-Value) & $\mathrm{R}$ & $\mathrm{R}^{2}$ & $\begin{array}{l}\mathrm{SEOE} \\
(\mathrm{mm})\end{array}$ \\
\hline 1 & $\begin{array}{c}\text { 2318.30-31.98 Lat.-16.72 Long. }+0.02 \\
\mathrm{~h}\end{array}$ & 0.003 & 0.450 ** & 0.203 & 177.5 \\
\hline 2 & $\begin{array}{c}\text { 17700.10-193.2 Lat.-185.93 Long.- } \\
10.93 \mathrm{~h}\end{array}$ & 0.001 & $0.950 * *$ & 0.903 & 157.3 \\
\hline 3 & $\begin{array}{c}-6634.5+96.570 \text { Lat. }+78.217 \\
\text { Long. }+0.235 \mathrm{~h}\end{array}$ & 0.000 & $0.990^{* *}$ & 0.980 & 14.38 \\
\hline 4 & $-388.251+21.164$ Lat. & 0.050 & $0.500 *$ & 0.250 & 59.7 \\
\hline 5 & $-205.450+11.830$ Lat. & 0.050 & $0.305^{*}$ & 0.093 & 101.4 \\
\hline 6 & - & - & - & - & - \\
\hline
\end{tabular}

Lat.: Latitude; Long.: Longitude; h: Height; R: Multiple Correlation Coefficient; $\mathrm{R}^{2}$ : Coefficient of Determination SEOE: Standard Error of Estimate; *Significant at 5 percent level $(\mathrm{P}<0.05)$; **Significant at 1 percent level $(\mathrm{P}<0.01)$; ns: non-significant.

Table 10 Regression models for interpolation of potential evapotranspiration data used for different climatic zones

\begin{tabular}{cccccc}
\hline Zones & Constant value with regression coefficients & Sig. (P-Value) & $\mathrm{R}$ & $\mathrm{R}^{2}$ & SEOE $(\mathrm{mm})$ \\
\hline 1 & $3327.80-55.04$ Lat.-5.58 Long.-0.23 h & 0.000 & $0.590^{* *}$ & 0.348 & 222.4 \\
2 & $-2873.20+54.80$ Lat.+32.40 Long.-0.13h & 0.000 & $0.890^{* *}$ & 0.792 & 46.5 \\
3 & $-12304.20-319.02$ Long.-1.31 h & 0.000 & $0.820^{* *}$ & 0.672 & 625.6 \\
4 & - & - & - & - & - \\
5 & $-4060.80-84.20$ Lat.-0.20 h & 0.000 & $0.590^{* *}$ & 0.348 & 319.8 \\
6 & $7036.7-145.50$ Lat.-0.90 h & 0.009 & $0.640^{* *}$ & 0.410 & 655.4
\end{tabular}

11

12

Lat.: Latitude; Long.: Longitude; h: Height; R: Multiple Correlation Coefficient; $\mathrm{R}^{2}$ : Coefficient of Determination SEOE: Standard Error of Estimate; *Significant at 5 percent level $(\mathrm{P}<0.05)$; $* *$ Significant at 1 percent level $(\mathrm{P}<0.01)$; ns: non-significant.

The latitude, longitude and height match significantly the changes for precipitation and potential evapotranspiration gradient in zones 1, 2 and 3 (Tables 9 and 10), but the relationship between independent variables and precipitation in zone 6 and potential evapotranspiration in zone 4 was not significant. In addition, there was a significant relation $(\mathrm{p}<0.05)$ for zones 4 and 5 between precipitation and latitude (Table 9) and between potential evapotranspiration and latitude and height $(\mathrm{p}<0.01)$ in zones 5 and 6 (Table 10). The results revealed that only the latitude was the affecting variable on precipitation gradient in zone 4 . Moreover, the water bodies in region could have an important influence on precipitation gradient in this zone (Masoudian 2011).

\subsubsection{Determining the interpolation method}

Different interpolation techniques were assessed using cross validation method to improve the zoning accuracy . Inverse distance weighting with power 2 and 5 were selected to interpolate the potential evapotranspiration and precipitation, respectively, on the basis of RMSE (Table 11). In addition, the kriging method was chosen to interpolate the average and the minimum temperature data. Accordingly, climate variable maps were prepared to show different zones across the country (Fig. 6 to 9).

Table 11 RMSE values of different interpolation methods for various variables

\begin{tabular}{cccccc}
\hline Variable & \multicolumn{3}{c}{ IDW (with power values) } & \multirow{2}{*}{ Kriging } \\
\cline { 2 - 5 } & 2 & 3 & 4 & 5 & \\
\hline Precipitation $(\mathrm{mm})$ & 386.1 & 378.6 & 376.2 & 375.5 & 381.2 \\
Potential Evapotranspiration $(\mathrm{mm})$ & 454.9 & 474.9 & 492.8 & 504.5 & 459.2 \\
Average Temperature $\left({ }^{\circ} \mathrm{C}\right)$ & 2.51 & 2.55 & 2.65 & 2.75 & 2.41 \\
Minimum Temperature $\left({ }^{\circ} \mathrm{C}\right)$ & 2.36 & 2.34 & 2.40 & 2.45 & 2.22 \\
\hline
\end{tabular}




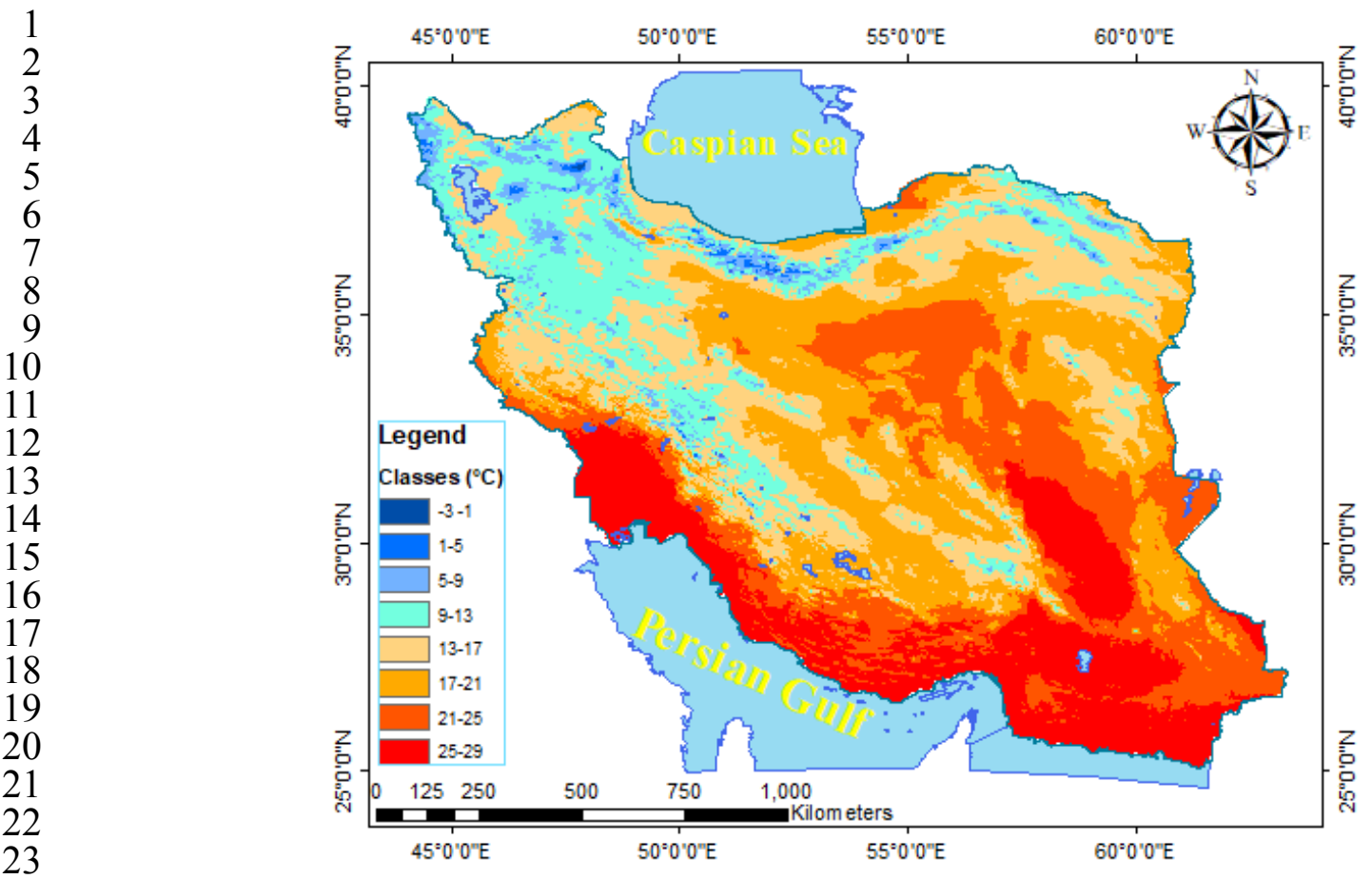

Fig. 6 Map of annual average of temperature zones

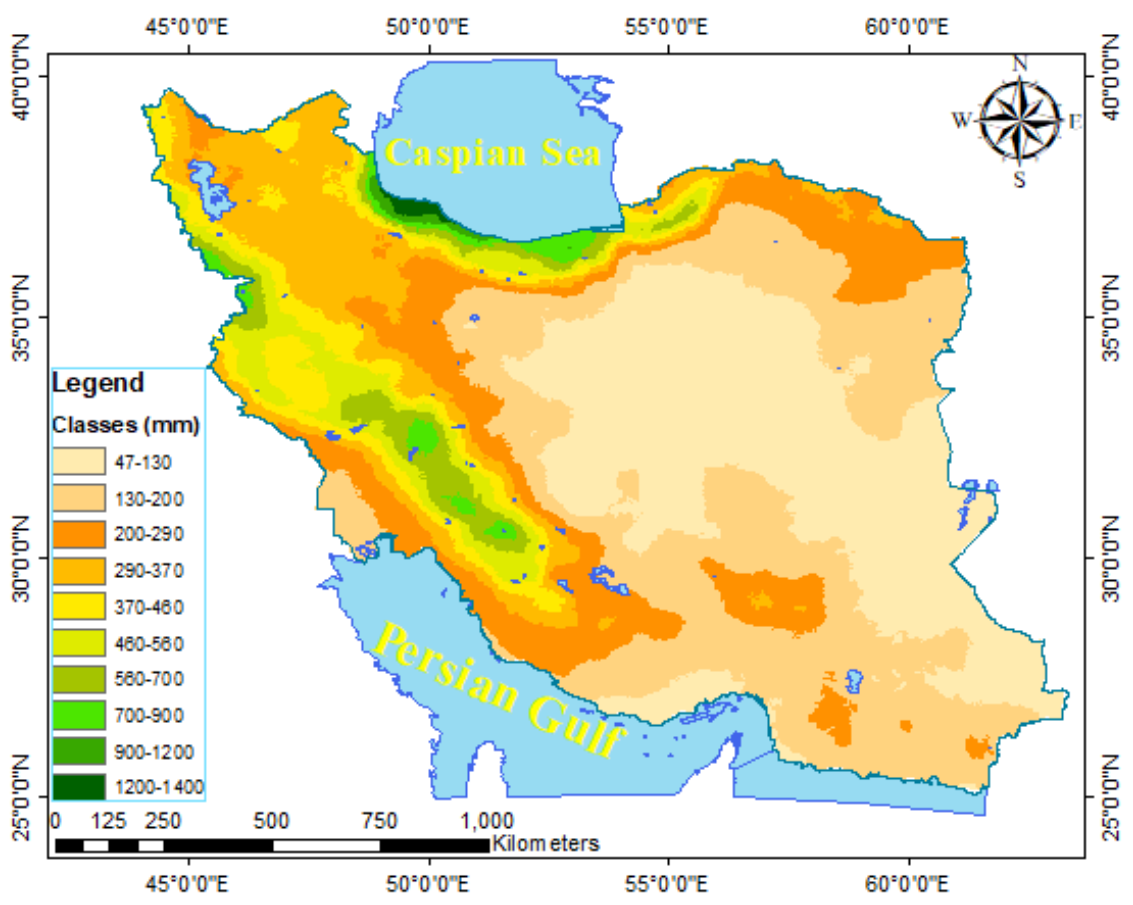

Fig. 7 Map of annual average of precipitation zones 


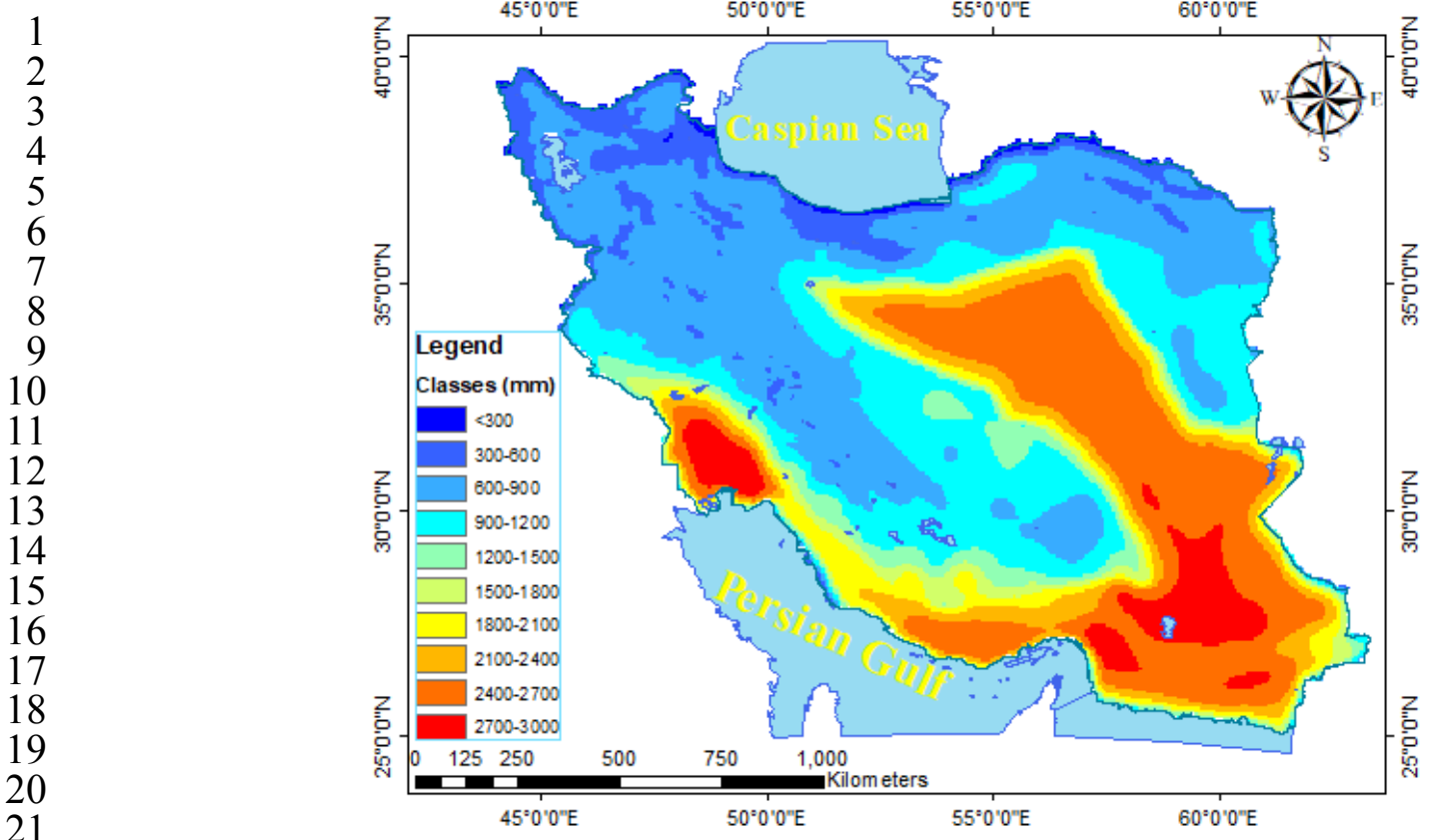

Fig. 8 Map of annual average of potential evapotranspiration zones

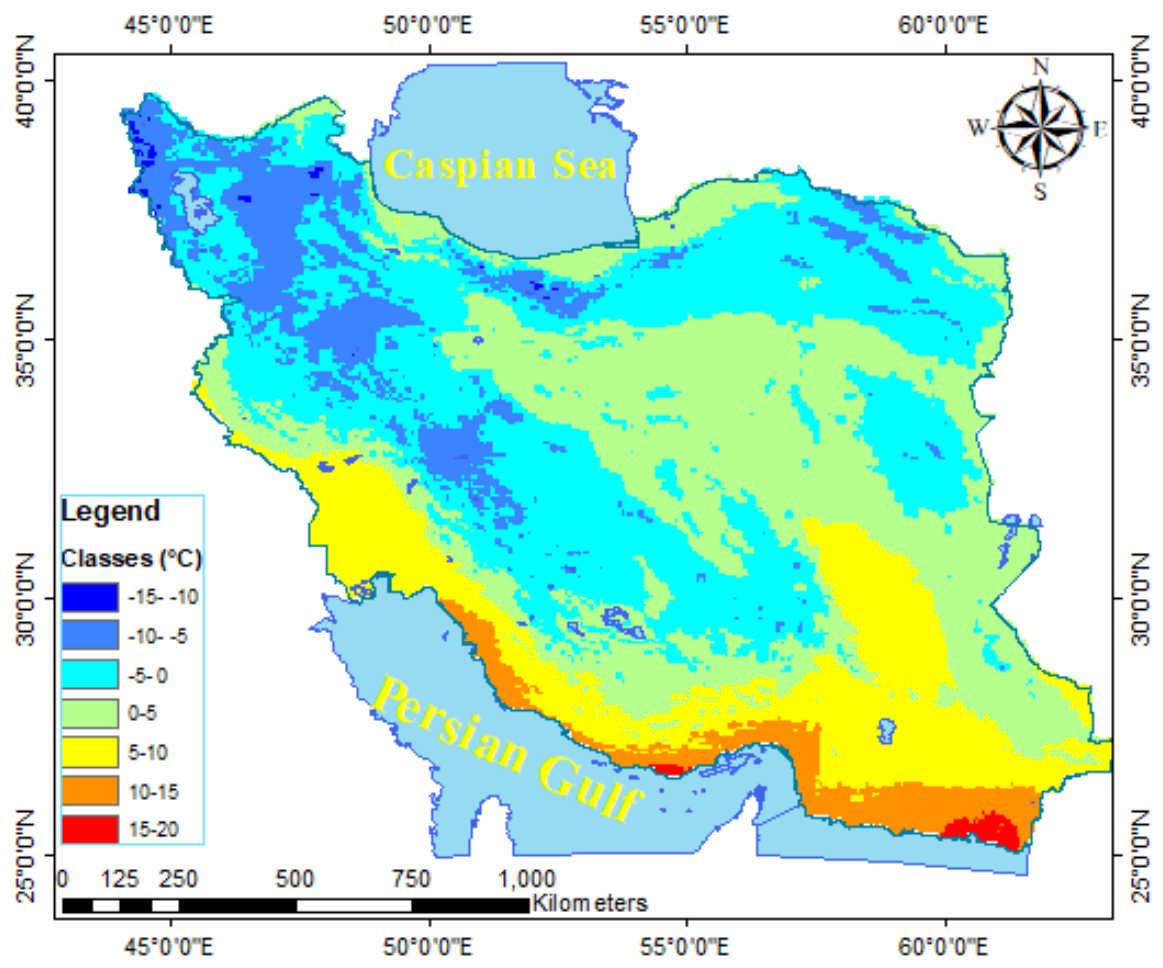

Fig. 9 Map of annual average of minimum temperature zones 


\subsection{Clustering}

Table 12 showed four climatic classes of different weather stations along with cluster membership according to clustering technique. The clustering results were comparable to the realities of climate across the country. The dendrogram of cluster analysis is represented in Figure 10.

Table 12 Mean and standard deviation of variables used in four clusters based on hierarchical clustering technique*

\begin{tabular}{lcccccccc}
\hline \multirow{2}{*}{ Variables } & \multicolumn{2}{c}{ Cluster 1 } & \multicolumn{2}{c}{ Cluster 2 } & \multicolumn{2}{c}{ Cluster 3 } & \multicolumn{2}{c}{ Cluster 4 } \\
\cline { 2 - 9 } & \multicolumn{2}{c}{$\mathrm{N}=5$} & \multicolumn{2}{c}{$\mathrm{N}=15$} & \multicolumn{2}{c}{$\mathrm{N}=9$} & \multicolumn{2}{c}{ N } \\
\cline { 2 - 9 } & Mean & Std. Dev & Mean & Std. Dev & Mean & Std. Dev & Mean & Std. Dev \\
\hline $\mathrm{T}_{\max }\left({ }^{\circ} \mathrm{C}\right)$ & 21.6 & 1.6 & 25.0 & 2.3 & 21.7 & 2.2 & 29.1 & 1.72 \\
\hline $\mathrm{T}_{\min }\left({ }^{\circ} \mathrm{C}\right)$ & 13.7 & 1.1 & 11.0 & 2.1 & 6.2 & 2.1 & 20.4 & 1.57 \\
\hline $\mathrm{P}(\mathrm{mm})$ & 1162 & 470 & 165 & 77 & 343 & 60 & 134 & 58 \\
\hline PET $(\mathrm{mm})$ & 815 & 31 & 926 & 153 & 702 & 87 & 2214 & 344 \\
\hline Ele $(\mathrm{m})$ & -13.2 & 12.7 & 1297.3 & 252.7 & 1474.2 & 252.6 & 93.2 & 7.9 \\
\hline Lat $\left({ }^{\circ}\right)$ & 37.04 & 0.30 & 33.31 & 2.61 & 35.30 & 1.82 & 29.05 & 2.33 \\
\hline Long $\left(\left(^{\circ}\right)\right.$ & 51.34 & 2.14 & 55.48 & 3.56 & 47.89 & 1.77 & 53.39 & 3.64 \\
\hline
\end{tabular}
precipitation, potential evapotranspiration, Elevation, Latitude and Longitude, respectively, for each cluster

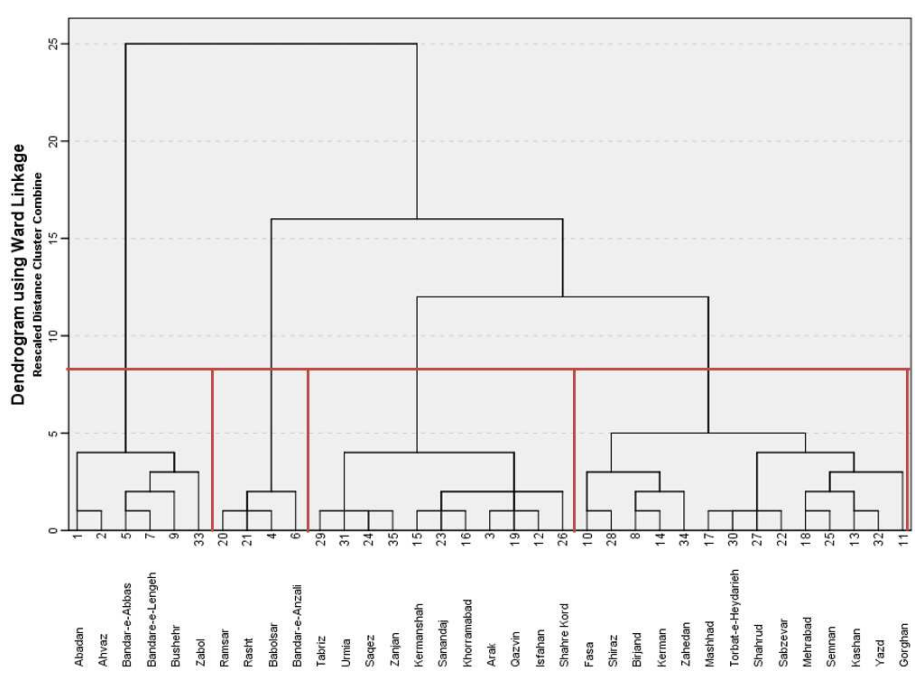

Fig. 10 Dendrogram of the weather stations based on the Ward's algorithm. Large changes of Euclidean distance show the best cut at value of 8 for four clusters which indicated by red boxes.

\section{Discussion}

Figure 11 shows the climatic zones using De Martonne method. The arid zone covers most of the country (69 percent), and 22 percent of Iran's climate is semi-arid. Moreover, the smallest climate zone belongs to per-humid type B (0.02 percent), with small patches in the northern part and in Zagros Mountains. Other climate types ranged from 1 to 3 percent of the total area (Fig. 11). 


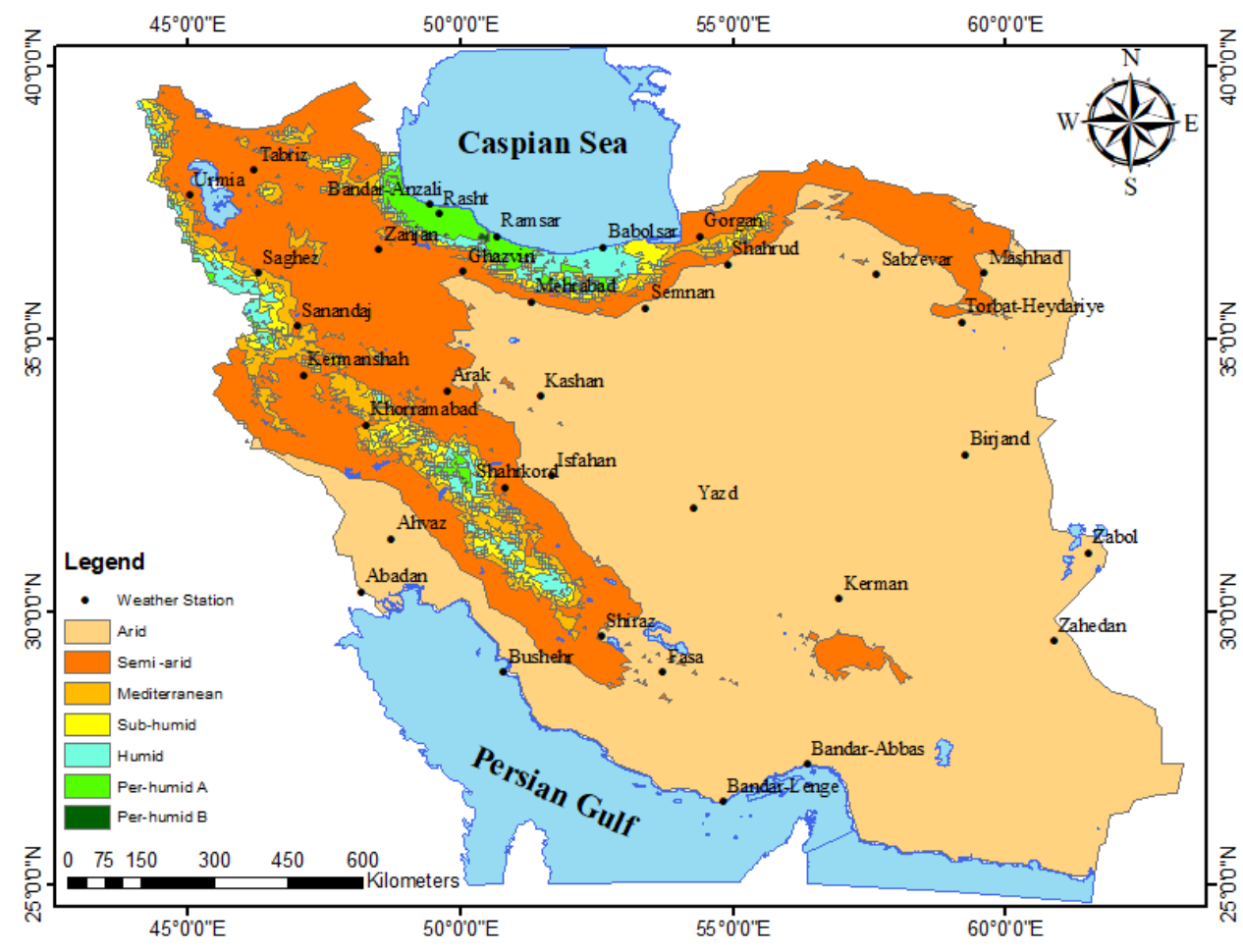

Fig. 11 Iran climate zones using DeMarton method

Figure 12 depicts the climatic regions using the T\&M method (T\&M 1955). It is obvious that both De Martonne and T\&M methods confirm the real climate types of Iran. However, T\&M method showed precipitation conditions with more details throughout the country. Moreover, storm cells in northern foothills of Alborz and western foothills of Zagros Mountains are prominence (Fig. 12) which emerges due to numerous numbers of humid subclasses in these methods. In an overview, a comparison between IRIMO and T\&M maps (Fig. 2 and 12) revealed that the climatic conditions of the climate classes with two methods were almost similar. The difference of these methods was that the dry climate class was much wider in the T\&M method, but in the IRIMO climate map, this area was divided into smaller microclimates. Moreover, the Caspian zone (north of the country) was divided into three classes in the T\&M map, but in IRIMO climate classification was presented just in one class. In the T\&M method, the changes in the humid zones of the Caspian Sea region were along the south-north direction and the semi-humid to very humid classes were seen in coastal area of the Caspian Sea. Regardless of both elevation and latitude, the T\&M method clearly showed the role of air masses and water bodies in diversity of humid climate zones in the country (Fig. 12). This is an important advantage of T\&M method which Feddema pointed out in his research that the method not only delineate climatic moisture gradients but also define a single seasonality index responsive to mean seasonal variation in both thermal and moist conditions, Feddema (2005). Some studies have also attempted to consider the atmospheric pressure patterns using a statistical approach (Heidari and Alijani 1999; Amirahmadi and Abbasnia 2010; Shi and Yang 2020). They concluded that ignoring the pressure patterns in empirical methods such as T\&M is a constraint. Nevertheless, the effectiveness of Caspian Sea moisture and altitude was well evident in T\&M classifications in Iran (Fig. 12). In addition, in this method the effect of moisture source distribution and variations in altitudes can be seen in western foothills of the Zagros Mountain. For example, Koohrang and Marivan areas in Zagros Mountain, were classified as mountainous humid climate, which is a new climate class. In Fact, the Zagros Mountains extends from SE to NW and blocks the warm-moist south westerly current air mass coming from Arabian Sea, north Indian Ocean and the Red Sea. Blockage mechanism intensifies the orographic ascending and heavy precipitation over the windward side and ridge lines of the continuous picks of the Zagros Mountains, and hence introduces a rational class of mountainous/highland climate, in this region of Iran. This new approach of climate of Iran is well detected by T \& M climatic classification system (1955). 


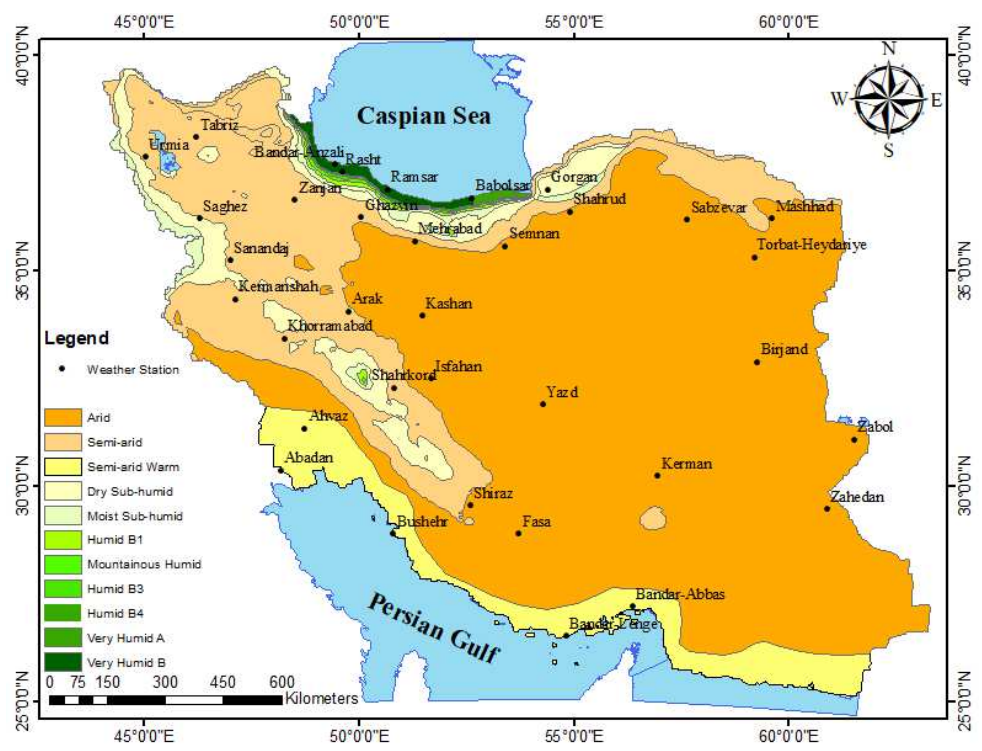

Fig. 12 Iran climate zones using T\&M method

In extended De Martonne climate classification (Khalili 1973) the country was divided into more microclimates as compared to T\&M method (Fig. 13). The dry zone in central Iran was divided into three categories, including warm arid, temperate arid and cold arid using extended De Martonne method. However, this region is categorized into one arid climate zone by T\&M method (Fig. 13).

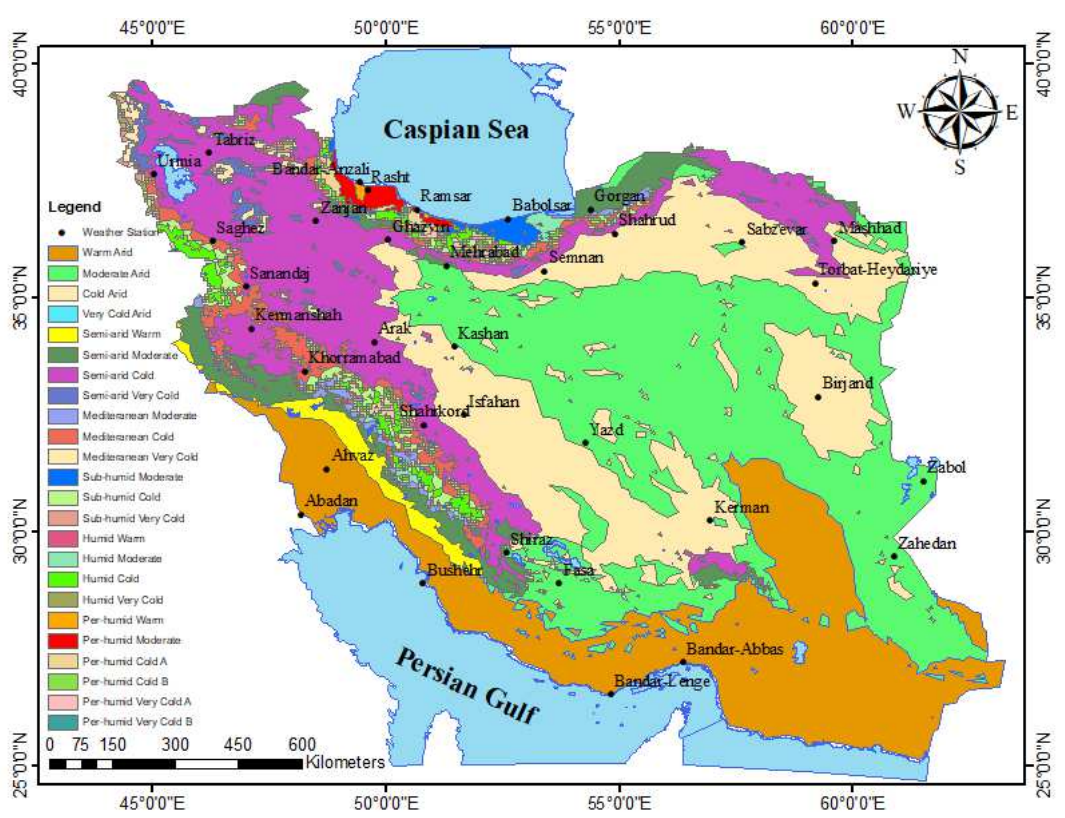

Fig. 13 Iran climate zones using extended De Martonne method

The results of the climate classification methods are comprised for 35 weather stations in table 13. Considering the minimum temperature as the third most effective variable, the Extended De Martonne method (Khalili, 1973) delineated more microclimates than the T\&M method (T\&M 1955). However, the remarkable differences in climate types of weather stations were found between Extended De Martonne and IRIMO methods, such as Isfahan, 
1 classification, the T\&M method clearly showed the role of water bodies and air masses for delineation of climatic 2 type in different regions. This is the main reason of superiority of this method amongst the others, Feddema (2005). 3 This was particularly found in the highlands/mountainous regions, in the vicinity of the Zagros Mountains (Fig. 12).

4

5

6

\begin{tabular}{|c|c|c|c|c|c|}
\hline $\mathrm{S} / \mathrm{N}$ & Weather stations & De Martonne & Extended De Martonne & $\mathrm{T} \& \mathrm{M}$ & IRIMO \\
\hline 1 & Abadan & Arid & Warm Arid & Arid & $\begin{array}{l}\text { Very warm with low } \\
\text { rainfall }\end{array}$ \\
\hline 2 & Ahvaz & Arid & Warm Arid & Arid & $\begin{array}{l}\text { Slightly hot with } \\
\text { moderate rainfall }\end{array}$ \\
\hline 3 & Arak & Semi-arid & Semi-arid Cold & Semi-arid & $\begin{array}{l}\text { Cold to very cold } \\
\text { with moderate } \\
\text { rainfall }\end{array}$ \\
\hline 4 & Babolsar & Humid & Sub-humid Moderate & Very humid A & $\begin{array}{l}\text { Moderate with a lot } \\
\text { of rainfall }\end{array}$ \\
\hline 5 & Bandar-e-Abbas & Arid & Warm Arid & Semi-arid Warm & $\begin{array}{l}\text { Very warm with low } \\
\text { rainfall }\end{array}$ \\
\hline 6 & Bandar-e-Anzali & Per-humid A & Per-humid Warm & Very humid B & $\begin{array}{l}\text { Moderate with a lot } \\
\text { of rainfall }\end{array}$ \\
\hline 7 & Bandare-e-lengeh & Arid & Warm Arid & Semi-arid Warm & $\begin{array}{l}\text { Very warm with low } \\
\text { rainfall }\end{array}$ \\
\hline 8 & Birjand & Arid & Cold Arid & Arid & Hot with low rainfall \\
\hline 9 & Bushehr & Arid & Warm Arid & Semi-arid Warm & $\begin{array}{l}\text { Very warm with low } \\
\text { rainfall }\end{array}$ \\
\hline 10 & Fasa & Arid & Moderate Arid & Arid & Hot with low rainfall \\
\hline 11 & Gorghan & Semi-arid & Semi-arid Moderate & Dry Sub-humid & $\begin{array}{l}\text { Moderate with a lot } \\
\text { of rainfall }\end{array}$ \\
\hline 12 & Isfahan & Arid & Cold Arid & Arid & Hot with low rainfall \\
\hline 13 & Kashan & Arid & Cold Arid & Arid & Hot with low rainfall \\
\hline 14 & Kerman & Arid & Cold Arid & Arid & Hot with low rainfall \\
\hline 15 & Kermanshah & Semi-arid & Semi-arid Cold & Semi-arid & $\begin{array}{l}\text { Cold to very cold } \\
\text { with moderate } \\
\text { rainfall }\end{array}$ \\
\hline 16 & Khorramabad & Semi-arid & Mediterranean Cold & Semi-arid & $\begin{array}{l}\text { old to very cold with } \\
\text { moderate rainfall }\end{array}$ \\
\hline 17 & Mashhad & Arid & Cold Arid & Arid & $\begin{array}{l}\text { Cold to very cold } \\
\text { with moderate } \\
\text { rainfall }\end{array}$ \\
\hline 18 & Mehrabad & Semi-arid & Moderate Arid & Semi-arid & Hot with low rainfall \\
\hline 19 & Qazvin & Semi-arid & Semi-arid Cold & Semi-arid & Hot with low rainfall \\
\hline 20 & Ramsar & Per-Humid A & Per-humid Moderate & Very humid B & $\begin{array}{l}\text { Moderate with a lot } \\
\text { of rainfall }\end{array}$ \\
\hline 21 & Rasht & Per-Humid A & Per-humid Moderate & Very humid B & $\begin{array}{l}\text { Moderate with a lot } \\
\text { of rainfall }\end{array}$ \\
\hline 22 & Sabzevar & Arid & Cold Arid & Arid & $\begin{array}{l}\text { Cold to very cold } \\
\text { with moderate } \\
\text { rainfall }\end{array}$ \\
\hline 23 & Sanandaj & Semi-arid & Semi-arid Cold & Semi-arid & $\begin{array}{l}\text { Cold to very cold } \\
\text { with moderate } \\
\text { rainfall }\end{array}$ \\
\hline 24 & Saqez & Mediterranean & Mediterranean Cold & Dry Sub humid & $\begin{array}{l}\text { Cold to very cold } \\
\text { with moderate } \\
\text { rainfall }\end{array}$ \\
\hline $\begin{array}{l}25 \\
26\end{array}$ & Semnan & $\begin{array}{c}\text { Arid } \\
\text { Somi }\end{array}$ & $\begin{array}{c}\text { Cold Arid } \\
\text { Comi }\end{array}$ & $\begin{array}{c}\text { Arid } \\
\text { Semi-arid }\end{array}$ & Hot with low rainfall \\
\hline 20 & ant & Sem1-arıd & Id Cold & & Cold to very cold \\
\hline
\end{tabular}

Table 13 Different climate classes for four climate classification systems 


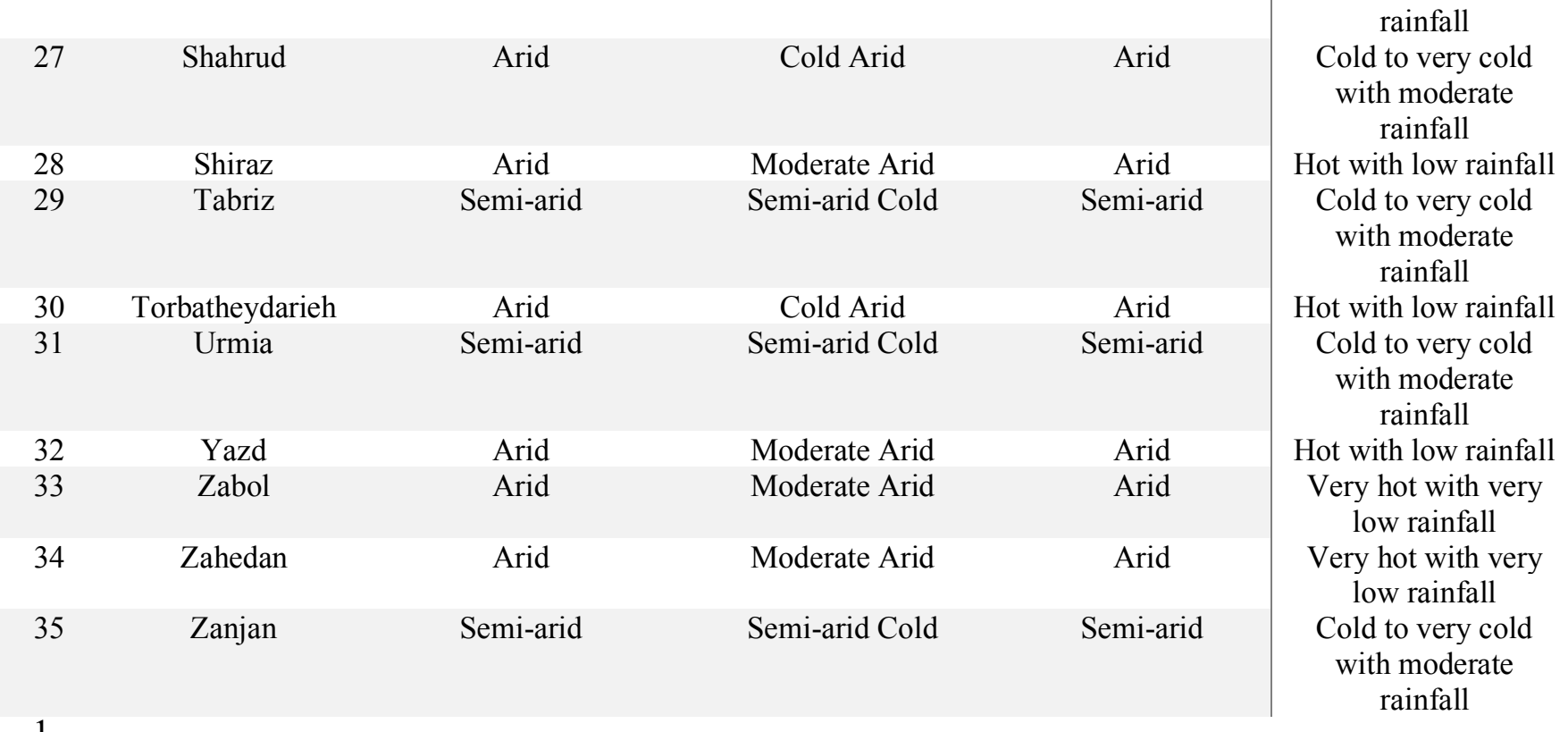

\section{4-1 Clustering}

The geographical distribution of weather stations for four clusters on the basis of Ward's algorithm is shown in Figure 14. The maximum and minimum number of weather stations (members) were observed in clusters 2 and 1 , respectively. When comparing the results of Ward's algorithm with other empirical methods, there are many similarities between climate groups.

11

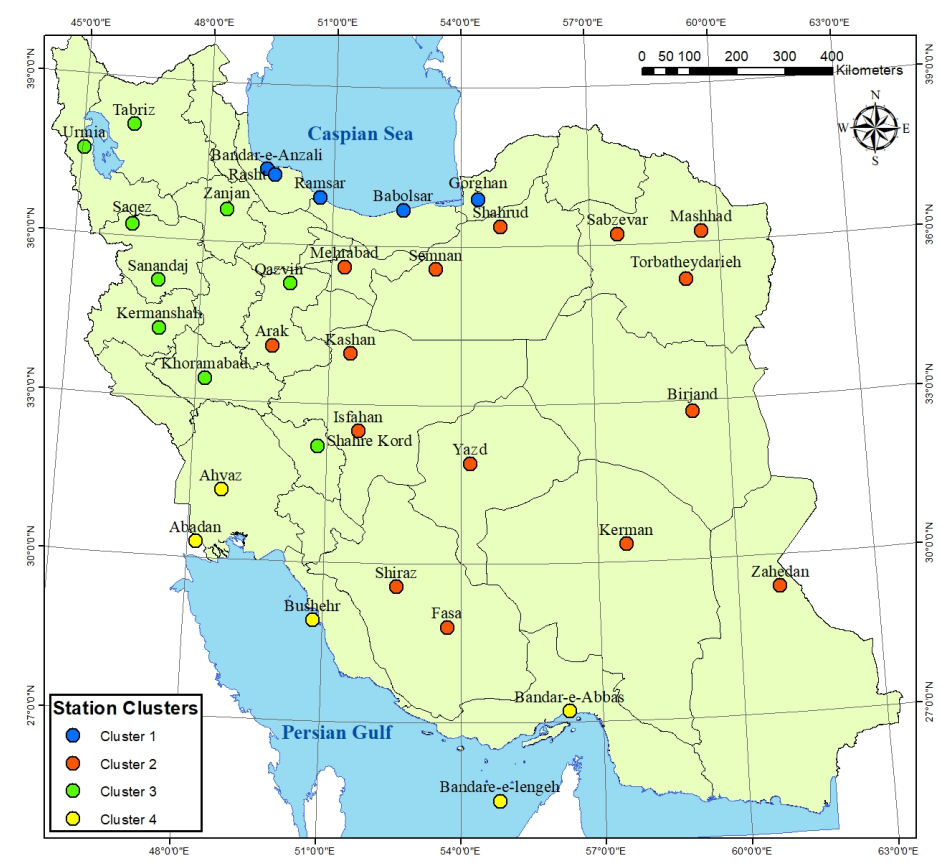

Fig. 14 Geographical distribution of weather stations among four clusters on the basis of Ward's algorithm 


\section{4-1-1 Cluster 1}

Of the total 35 weather stations, this cluster had 5 members and included 14.3 percent of total stations. They are located at the Caspian Sea shore (North of the country) with a climate of very humid (Figure 14). This cluster has the mean annual maximum and minimum temperatures, precipitation and evapotranspiration of $21.6{ }^{\circ} \mathrm{C}, 13.7{ }^{\circ} \mathrm{C}$, $1162 \mathrm{~mm}$ and $815 \mathrm{~mm}$, respectively (Table 12) which is comparable with results obtained by T\&M climate classification (Figure 12).

\section{4-1-2 Cluster 2}

This cluster had the largest number of members ( 15 members $)$ and consisted of 40 percent of total stations. Weather stations are distributed in center, southeast, and northeast of the country (Figure 14). The climate of the cluster 2 is arid and similar to that of T\&M, De Martonne methods. This region of the country has low precipitation, less than $165 \mathrm{~mm}$, with an annual average of maximum temperature of 25 degree Celsius (Table 12).

\section{4-1-3 Cluster 3}

Cluster 3 was a cluster with 9 members which included the stations located in the direction of northwest to southwest of the Zagros Mountains (Figure 14). The most prominent feature of this cluster was a mean annual minimum temperature of $6.2^{\circ} \mathrm{C}$ which was the lowest temperature between clusters (Table 12). The climate of this region is semi-arid and comparable with that of T\&M and De Martonne methods.

\section{4-1-4 Cluster 4}

The number of members in this cluster consisted of 6 weather stations. The stations were located at the coast of the Persian Gulf. The climate of the cluster 4 is semi-arid warm whish is similar to T\&M climate classification. The most important characteristic of this cluster was very high mean annual temperature and potential evapotranspiration rate, $29.1{ }^{\circ} \mathrm{C}$ and $2214 \mathrm{~mm}$, respectively (Table 12 ).

The results revealed that the clusters obtained from Ward's algorithm are comparable to those of empirical climate classifications, particularly Thornthwaite and Mather method.

\section{Conclusions}

In this research, the Thornthwaite and Mather climatic classification system was used to classify the climate of Iran. The results were compared to those of De Martonne, Extended De Martonne, and IRIMO methods. Thornthwaite and Mather method provided a more accurate recognition of climate classes in Iran, especially in mountainous regions of the country in western regions: while in the De Martonne and the Extended De Martonne methods, the Zagros storm cell in the west of Iran was climatically classified similar to patchy areas in Caspian Sea coastal zone, this cell was classified as a new zone in modified Thornthwaite and Mather method. Accordingly, the humid B zone for the Zagros storm cell was changed to the highland/mountainous humid climate which embraces Koohrang, Yasuj, Sardasht and Marivan region. In fact, in the Thornthwaite and Mather method, we modified the humid B class into the highland/mountainous humid climate to be similar to IRIMO method as a reference method. In addition, from a synoptic point of view, the Thornthwaite and Mather method is reliable to identifying the role of the tropical sea and ocean on precipitation patterns over mountainous regions in west of Iran. The clustering results, Ward's hierarchical agglomerative method, were comparable to the realities of climate across the country. The results revealed that the clusters obtained from Ward's algorithm are comparable to those of empirical climate classifications, particularly Thornthwaite and Mather method. In conclusion, since the climate classification approach used by Thornthwaite and Mather was more rational and practical for Iran, this method is recommended as a framework leading environmental project management to improve the quality of life in the region.

\section{Author's Contribution}

Material preparation and data collection were performed by Faezeh Abbasi and Saeed Bazgeer. The statistical analysis was done by Saeed Bazgeer, Ebrahim Asadi Oskoue and Masoud Haghighat. The first draft of the manuscript was prepared by Faezeh Abbasi, Saeed Bazgeer and Parviz Rezazadeh Kalehbasti. The interpretation of the Maps was done by Saeed Bazgeer, Parviz Rezazadeh Kalehbasti, Ebrahim Asadi Oskoue and Masoud 
Haghighat. The final version of manuscript was written by Saeed Bazgeer, Parviz Rezazadeh Kalehbasti and Pouya Rezazadeh Kalebasti.

\section{References}

1- Abounoori AA (2010) Analysis of agricultural drought phenomenon in Ramsar city by Thornthwaite method. J Geographical Space 28: 1-39.

2- Adl AH (1960) Climatic divisions and vegetation of Iran. University of Tehran Publications, Tehran

3- Aguilar E, Auer I, Brunet M, Peterson TC, Wieringa J (2003) Guidance on metadata and homogenization. WMO Td. 1186:1-53

4- Alavipanah SK, Shamsipour AA, Amiri R (2007) a study of the relationship among temperatures of surface features and its application in remote sensing study of Lut desert. J Desert 12: 85-97. https://.org/0.22059/jdesert.2008.31070

5- Alexanderson H, Moberg A (1997) Homogenization of Swedish temperature data Part 1: homogeneity test for linear trends. Int J Climatol 17: 25-34. https://doi.org/10.1002/(SICI)10970088(199701)17:1<25::AID-JOC103>3.0.CO;2-J

6- Aparecido LEDO, Rolim GDS, Richetti J, Souza PSD, Johann JA (2016) Köppen, Thornthwaite and Camargo climate classifications for climatic zoning in the State of Paraná. CIENC AGROTEC 40:405417. https://doi.org/10.1590/1413-70542016404003916

7- Baltas E (2007) spatial distribution of climatic indices in northern Greece. METEOROL APPL 14:69-78. https://doi.org/10.1002/met.7

8- Bazrafshan Daryasari M, Meftah Halghi M, Gorbani Kh, Ghahraman N (2016) Comparative study of climate regions of Golestan province under different climate change scenarios. J water and soil conservation, 22:187-202

9- Buishand TA (1982) some methods for testing the homogeneity of rainfall records. J HYDROL 58: 1127. https://doi.org/10.1016/0022-1694(82)90066-X

10- De Martonne E (1941) Traite de Geographie Physique: 3 tomes, Paris. Flocas AA. 1994. Courses of Meteorology and Climatology. Ziti Publications: Thessaloniki

11- Feddema JJ (2005) A revised Thornthwaite-type global climate classification. Phys. Geogr 26:442-466. https://doi.org/10.2747/0272-3646.26.6.442

12- Ganji MH (1954) Iran's climatic divisions. Faculty of Literature, University of Tehran, Tehran, Iran 9: 147

13- Ghaemi H, Zarrin A, Khosh Akhlagh F (2012) Climatology of Arid Regions. Samt Publications, Tehran, Iran

14- Ghaffari A, Ghasemi VR, De Pauw E (2015) Agro-Climatology Zoning of Iran by UNESCO approach approach J. Dryland Agric 4: 63-95

15- Ghorbani Kh, AghaShariatmadary, Z (2014) The effect of local gradients on increasing of climate data interpolation accuracy by geographically weighted regression (case study: Air temperature and relative humidity), Journal of Watershed Management Research, 10:132-143

16- Ghorbani Kh, Bazrafshan Daryasari M, Meftah Halaghi M, Ghahreman N (2016) The effect of climate change on DeMarton climate classification in Golestan province, J Soil and Water Research, 47:319-332

17- Golkar Hamzee Yazd HR, Rezayinezhad, M, Tavousi, M (2016) Climate zoing of south Khorasan province with GIS software, J Water and Soil Resources Conservation, 6:47-60.

18- Heidari H, Alijani, B (2000) Climatic Classification of Iran using multivariate statistical techniques, J geographical research quarterly, 37:57-74

19- IRIMO (2016) Applied meteorological development plan report, No.1, Agricultural Meteorology

20- Jain AK, Murty MN, Flynn PJ (1999) Data Clustering: A Review. ACM Computing Surveys. 31: 264323

21- Javadi C (1966) Distribution climatiques en Iran. Monographie Meteorol Nat, Paris

22- Kent P, Jensen RK, Kongsted, A (2014) A comparison of three clustering methods for finding subgroups in MRI, SMS or clinical data: SPSS twostep cluster analysis, latent Gold and SNOB. BMC Med. Res. Methodol. 14:113. doi: 10.1186/1471-2288-14-113

23- Khalili A (1973) The scientific understanding of climate and weather. IRIMO publication, Tehran

24- Köppen W (1900) Versucheiner Klassifikation der Klimate, vorzugsweise nach ihren Beziehungen zur Pflanzenwelt, Geographische Zeitschrift, 6:657-679

25- Köppen W (1931) Grundriss der Klimakunde, Walter de Gruyter and Co: Berlin 
26- Leech G (2014). Classification of Arid \& Semi-Arid Areas: A Case Study in Western Australia. J ANU Undergraduate Research, 5: 79-100

27- Masoudian SA (2003).Climatic regions of Iran, Geography and Development Iranian J, 2:171-184. https://doi.org /10.22111/gdij.2003.3821

28- Masoudian SA (2011) Climate of Iran, University of Isfahan Press, Isfahan, Iran

29- Mavrakis A, Papavasileiou H (2013) NDVI and E. de Martonne indices in an environmentally stressed area (Thriasio Plain-Greece). Proc. Technol 8:477-481. https:// doi: 10.1016/j.protcy.2013.11.062

30- Mirmousavi SH, Kiani H (2017) An investigation on Copen's Climate Classification in 1975 in Comparison with the Output of MIROC in the years 2030, 2050, 2080, and 2100 under Scenario A1B and A2, J Geography and Environmental Hazards, 7:59-72

31- Moradian M (2016) Comparison of Geopotential height anomalies of atmospheric lower levels in drought and wet years of Iran, (Master thesis, University of Tehran)

32- Müller MDS, Dourado-Neto D, Timm LC, Reichardt K, Sartori FF, Felisberto G (2018) Climate analysis for agricultural improvement of the Economic Community of West African States according to Köppen and Thornthwaite. African J Agricultural Research, 13: 1198-1212. https://doi.org /10.5897/AJAR2018.13064

33- Netzel P, Stepinski T (2016) on using a clustering approach for global climate classification. J Climate, 29:3387-3401 https://doi.org/10.1175/JCLI-D-15-0640.1

34- Norusis MJ (2010) Chapter 16: Cluster analysis. PASW Statistics 18 Statistical Procedures Companion (pp. 361-391). Upper Saddle River, NJ: Prentice Hall

35- Nouri Mohammadiyeh M, Mohammadi M, Sohrabi T (2009) Calibration of modified Thornthwaite method in calculation of potential evapotranspiration (Case study: Safidrood Basin), International Conference on Water Resources, Shahrood University of Technology, 1-8

36- Petit AN (1979) A non-parametric approach to the change-point detection, J Appl Stat 28:126-135. https://doi.org/10.2307/2346729

37- Piri I, Khanamani A, Shojaei S, Fathizad H (2017) Determination of the best geostatistical method for climatic zoning in Iran. APPL ECOL ENV RES 15: 93-103 http://dx.doi.org/ 10.15666/aeer/1501_093103

38- Poormohammadi S, Malekinezhad H (2013) Classification of homogeneous climate regions under the impact of climate change and greenhouse gas emissions scenarios using L-Moments technique in Iran, J Watershed Management Research, 8:58-76

39- Rahimi J, Ebrahimpour M, Khalili A (2013) spatial changes of extended De Martonne climatic zones affected by climate change in Iran. THEOR APPL CLIMATOL 112:409-418 https://doi.org/10.1007/s00704-012-0741-8

40- Raziei T (2017) Köppen-Geiger climate classification of Iran and investigation of its changes during 20th century, J the Earth and Space Physics, 43: 419-439

41- Rubel F, Brugger K, Haslinger K, Auer I (2017) the climate of the European Alps: Shift of very high resolution Köppen-Geiger climate zones 1800-2100. Meteorol. Z. 26(2), 115-125 DOI: $10.1127 /$ metz/2016/0816

42- Siabi N, Sanaeinejad H (2013) An investigation into using of combined geostatistical methods to increase precision in climatology classification and climate parameters zoing in great Khorasan, $\mathrm{J}$ Climatological Research 15: 81-92

43- Shi J, Yang L (2020) A Climate Classification of China through k-Nearest-Neighbor and Sparse Subspace Representation. J Climate, 33: 243-262. https://doi.org/10.1175/JCLI-D-18-0718.1

44- Thornthwaite CW, Mather JR (1955). The water balance. Publications in climatology

45- Thornthwaite CW, (1948). An approach toward a rational classification of climate. Geogr Rev 38: 55-94. DOI: $10.2307 / 210739$ 
46- Umar R, Yusuf M (2019) Determination of the Growing Season for Dry Land Agriculture Based on Thornthwaite Method in Bulukumba Regency. South Sulawesi Province. J Phys Conf Ser. https://doi.org /10.1088/1742-6596/1244/1/012032

47- Vieira MT, Meireles AC, de Oliveira C W, do Nascimento MT (2017) Koppen-Geiger and Thornthwaite climatic classification for the metropolitan region of the Cariri, Ceará. J Revista Geama, 3:136-143

48- Wijngaard, JB, Klein Tank AMG, Können GP (2003) Homogeneity of 20th century European daily temperature and precipitation series. INT J CLIMATOL 23: 679-692. https://doi.org/10.1002/joc.906

49- Worsley KJ (1979) on the likelihood ratio test for a shift in location of normal populations. J Am Stat Assoc 47: 365-367. https://doi.org/10.1080/01621459.1979.10482519

50- Zarei R, Sarajian M, Bazgeer S (2013) Monitoring Meteorological Drought in Iran Using Remote Sensing and Drought Indices. J Desert 18: 89-97. doi 10.22059/JDESERT.2013.36279

51- Zareiee AR (2014) Evaluation of changes in different climates of Iran, using De Martonne index and Mann-Kendall trend test. NAT HAZAED EARTH SYS 2:2245-2261 https://doi.org/10.5194/nhessd-22245-2014 